\title{
A MISSING LINK IN EUROPEAN TRAVEL LITERATURE BURCHARD OF MOUNT SION'S DESCRIPTION OF EGYPT*
}

\author{
JONATHAN RUBIN \\ BAR ILAN UNIVERSITY
}

\begin{abstract}
This article offers a first study and edition of Burchard of Mount Sion's 'Egyptian section'. This text-hitherto almost completely neglected by scholars-provides a detailed account of Egypt, and is preserved in its entirety in two manuscripts, following Burchard's Descriptio Terrae Sanctae. The present work provides an analysis of the contents and characteristics of this text, of the cultural context in which it was composed, and of its reception in medieval and early modern times. Appendix 1 includes a provisional edition of Burchard's account of Egypt. Appendix 2 offers an edition of the final part of a shortened version of this text which is significant from the point of view of the history of its reception.
\end{abstract}

Key Words

Burchard of Mount Sion, Egypt, Travel literature, Nile, pilgrimage.

The number of medieval Latin travel accounts describing Egypt preceding the end of the Frankish or Crusader period is very limited. Indeed, for the period of Latin dominance in Syria (1099-1291) only one such text reached us. This is

* I would like to thank Paolo Trovato, Charles Burnett and the anonymous reviewers of Mediterranea for their useful comments on drafts of this paper. I am also grateful to Tobias Funke and Ishayahu Landa for their help in obtaining materials from Germany which were essential for the preparation of this article. This research was supported by the Israel Science Foundation (grant no. 1443/17). 
Burchard of Strasbourg's description, dating to $1175,{ }^{1}$ to which may be added several brief and partial accounts of this region by Franks who visited Egypt. ${ }^{2}$ Against this background, it is very significant that there exists a highly elaborate thirteenth-century Latin travel account of Egypt, which has hitherto remained almost completely neglected by scholars: this text was composed by Burchard of Mount Sion and appears, in some manuscripts, following his extremely wellknown description of the Holy Land, or Descriptio Terrae Sanctae. Burchard was a Dominican friar who traveled in the Eastern Mediterranean in the 1280s, at least occasionally, as a diplomatic envoy. As we shall see below, he seems to have been strongly connected to the Latin kingdom of Jerusalem and may have belonged to the Dominican province of the Holy Land. ${ }^{3}$

The aim of this article is to present for the first time Burchard's account of Egypt, examining its content and characteristics, but also looking at what this text can tell us about Burchard's work as an author as well as about his cultural environment. As will be seen, the shift from the description of the Holy Land to that of Egypt represents an important moment in the history of Western travel literature. The final sections of the article are devoted to the reception of Burchard's account of Egypt in medieval and early modern times. Two appendices are attached to this article: the first includes a tentative edition of Burchard's account of Egypt, and the second presents an edition of the final part of a shortened version of this text which is studied below and referred to as the 'abbreviated version'.

That the discussions of Western writing concerning Egypt make no mention of Burchard's Egyptian section is easy to explain: ${ }^{4}$ Laurent's edition, which is the

1 For Burchard of Strasbourg's work, see Paul Lehmann and Otto Glauning, 'Mittelalterliche Handschriftenbruchstücke der Universitätsbibliothek und des Georgianum zu München', Zentralblatt für Bibliothekswesen, Beiheft 72 (1940), pp. 61-73 [referred to below as 'Burchard of Strasbourg, Itinerarium']. A version of it also appears in: Arnold of Lübeck, Chronica Slavorum, ed. Johann M. Lappenberg, (Monumenta Germaniae Historica Scriptores, 21), Hanover: Hahnianus, 1869, pp 235-241. The description of Egypt is found at pp. 236-239.

2 Among the authors of these accounts, one should mention Jean de Joinville, who accompanied King Louis IX on his Seventh Crusade and included in the text he later composed considerable information concerning Egypt. See, for example, his discussion of the Nile: Jean de Joinville, Vie de Saint Louis, ed. and trans. Jacques Monfrin, Paris: Garnier, 2010, pp. 92-95, pars. 187-191. Similarly, Jacques de Vitry also spent some time in Egypt and included comments concerning it in both his letters and the Historia orientalis. See, in particular, Jacques de Vitry, Lettres, ed. Robert B. C. Huygens, Turnhout: Brepols, 2000, pp. 584-588.

3 For the only critical edition of this text (which does not include Burchard's account of Egypt), see Johann C. M. Laurent (ed.), Peregrinatores medii aevi quatuor, Leipzig: Hinrichs, 1864, pp. 3-94. For biographical information on Burchard, see Jonathan Rubin, 'Burchard of Mount Sion's Descriptio Terrae Sanctae: A Newly Discovered Extended Version', Crusades 13 (2014), pp. 173-190.

4 See, for example, Burnett's discussion of travel accounts of Egypt in Charles Burnett, 'Images of Ancient Egypt in the Latin Middle Ages', in Peter Ucko and Timothy Champion (eds), The Wisdom of Egypt, London: UCL Press, 2003, pp. 68-70. Burchard's work is also not mentioned in John P. 
only critical edition of Burchard's work, does not provide it, and so scholars were unlikely to suspect that the Descriptio ever included such a text. Laurent himself was aware that some textual witnesses of Burchard's work present an account of Egypt, but rejected its authenticity on the basis of a comment, placed at the beginning of the text, where Burchard states that his work was limited to the description of the Holy Land..$^{5}$ The publication of a textual witness which provides the 'abbreviated version' of Burchard's account of Egypt-in 1903, by Henri Omont-did not clarify this question, since his article was limited to one manuscript and did not shed light on the textual tradition of the Descriptio. Thus, scholars who were aware of this publication nevertheless remained hesitant as to the authenticity of this section. ${ }^{6}$

Recent studies on some previously neglected manuscripts of the Descriptio provide a clear solution to this doubt. I have recently published a part of a manuscript, now in London (British Library, Add. 18929, referred to below as 'MS London'), which provides, following a text roughly parallel to that published by Laurent, an account of Burchard's travels to Egypt, Sicily, Italy and then back to the East. ${ }^{7}$ An additional manuscript (MS Zwickau, Ratsschulbibliothek, 1.12.5, referred to below as 'MS Zwickau') includes most of these sections, including the description of Egypt, but ends with the account of Lucca. ${ }^{8}$ That the sections dealing with Burchard's travels outside the Holy Land are indeed authentic and

Cooper, The Medieval Nile: Route, Navigation and Landscape in Islamic Egypt, Cairo: The American University in Cairo Press, 2014. This text is also not utilized in a very detailed paper on the traditions and sites related to Christ and his family's sojourn in Egypt: Beatrice Saletti, 'La sacra famiglia in Egitto: Pellegrini europei al Cairo tra XIV e XVI secolo', Nuova Rivista Storica, 98/3 (2014), pp. 909-960. Notably, the only scholars who seem to have hitherto used this text are those who worked on Egypt's image in medieval German literature. However, the text they used, a 1584 German printed edition, is so far removed from Burchard's original work that its study is hardly instructive for understanding the actual medieval composition. See Abbas Amin, Ägyptomanie und Orientalismus: Ägypten in der deutschen Reiseliteratur, 1175-1663, Berlin: De Gruyter, 2013; Aleya Khattab, Das Ägyptenbild in den deutschsprachigen Reisebeschreibungen der Zeit von 12851500, Frankfurt: Peter Lang, 1982.

5 Laurent (ed.), Peregrinatores, p. 12.

6 Henri Omont, 'Manuscrits de la bibliothèque de sir Thomas Phillipps récemment acquis pour la Bibliothèque nationale', Bibliothèque de l'École des Chartes 64 (1903), pp. 490-553. Baumgärtner, who was not only aware of Omont's publication, but also identified an additional manuscript which transmits a section concerning Egypt, remained skeptical as to whether this part of the work was penned by Burchard; see Ingrid Baumgärtner, 'Burchard of Mount Sion and the Holy Land', Peregrinations: Journal of Medieval Art and Architecture 4/1 (Spring 2013), pp. 14-15.

Rubin, 'Burchard', pp. 173-190.

8 For the ending of MS Zwickau, see fol. 144v, and cf. Rubin, 'Burchard', p. 189. Both MSS were alluded to by Rotter in a paper of which I was unaware when I published my 2014 paper: Ekkehart Rotter, 'Windrose statt Landkarte. Die geografische Systematisierung des Heiligen Landes und ihre Visualisierung durch Burchardus de Monte Sion um 1285', Deutsches Archiv für Erforschung des Mittelalters 69 (2013), pp. 47, n. 8; 70-71, n. 77 et passim. Rotter, however, did not study these MSS in detail or publish sections from them. 
were authored by Burchard seems unquestionable. This is made clear by the dates which are provided throughout the London/Zwickau version of the Descriptio and which together produce a coherent picture of Burchard's movements around the Mediterranean..$^{9}$ It is hard to see why a later scribe/editor would have been interested in making up such a sequence, and how he would have been able to produce one. Furthermore, various details concerning Burchard's biography and, in particular, his status as a Dominican friar, are also attested to in different sections of the London manuscript: at the beginning of the text as transmitted by this manuscript Burchard refers to himself as 'ego Burchardus ordinis predicatorum' ('I Burchard of the Order of Preachers'). Later, as he describes his visit to Rome, he describes two Dominican institutionsSancta Maria in Minerva and Sancta Sabina in monte Aventino-as places 'ubi stant fratres' ('where there are friars'). ${ }^{10}$ Additionally, one reads in the London text that Burchard went to Bologna in 1285 to meet the head of the Dominican order. Indeed, this seems to further confirm the authenticity of this text, since the Dominicans held their general chapter in the city that year. ${ }^{11}$ To these points one should add some considerations of stylistic nature: several forms of expression appear in both the Descriptio as published by Laurent and in the 'new' parts of the text, suggesting that they were all written by the same person. Among these are: 'stupor est videre' and 'quantum potui... consideravi/indagavi/investigavi'. ${ }^{12}$ It is thus certain that the Egyptian section as provided by the London and Zwickau manuscripts was indeed composed by Burchard, although, as is often the case, it may also include some later scribal interventions. ${ }^{13}$

13 A complete detailed and updated list and survey of all extant manuscripts of the Descriptio remains a desideratum which the author of this paper hopes to fulfill. Of the twenty manuscripts which I have hitherto been able to explore only London and Zwickau include the complete Egyptian section, while several others include the 'abbreviated version' to which we shall return toward the end of this paper. This conclusion is supported also by Rotter, who examined a very considerable number of manuscripts and included them in his (incomplete) list. Indeed, he writes that only the London and Zwickau manuscripts transmit Burchard's travel from the Holy Land back to the West; see Rotter, 'Windrose', p. 70, n. 77 (the manuscript lists appear at pp. 103-106). For previous lists of manuscripts of the Descriptio, see Reinhold Röhricht, Bibliotheca Geographica Palaestinae, Berlin: Reuther, 1890, pp. 56-58; Thomas Kaeppeli, Scriptores Ordinis Praedicatorum Medii Aevi, 4 vols, Rome: Ad S. Sabinae, 1970-1993, vol. I, pp. 257260.
} 


\section{Characteristics and Content of the Egyptian Section}

Burchard's Descriptio Terrae Sanctae, as known to scholars through Laurent's 1864 edition, is a very detailed account of biblical geography of the Holy Land, related to contemporary actuality on the basis, at least in part, of the author's own experience, and often commended for being extraordinarily systematic. Taking Acre as the 'centre', Burchard drew four imaginary lines in conformity with the cardinal points, and then divided each of the quarters thus created into three subsections. ${ }^{14}$ The greater part of his text, as provided by Laurent's edition, is made up of the detailed description of these sections, followed by three thematic chapters: on the length and breadth of the Holy Land, on its fruits and animals, and on the religious groups inhabiting it. Thus, Burchard's composition, as represented by Laurent's edition, could have justly been seen as a well-ordered and carefully preconceived discussion of the Holy Land.

But this major characteristic of the Descriptio does not apply to the newly discovered sections, which appear in the London and Zwickau manuscripts, the first of which provides the account of Egypt. Here one finds no introductory comments of the sort Burchard provided for his discussion of the Holy Land and no thematic or geographical plan can be recognized, except the sequence of his movement through space. Notably, the shift from a text based on a preconceived geographical logic to a narrative which follows the author's itinerary occurs within the text published by Laurent. However, since the text is truncated, this move could not have been appreciated for what it was. The discovery of the sections following the Descriptio as published by Laurent makes such an analysis possible for the first time. Given its significance for both the understanding of Burchard as an author and, as we shall see below, for the appreciation of an important moment in the history of Western travel literature, it is expedient to look at it in some detail.

Having described the Holy Land's various religious groups, Burchard argues that the great majority of population in the East, except Arabia and Egypt, is Christian, and it is only because these Christians are ruled by non-Christians that these territories are considered Muslim. ${ }^{15}$ In order to support this argument, Burchard shares with his readers experiences from his sojourn in Armenia, thus breaking both with his original intention to restrict his work to the Holy Land

14 Denys Pringle, Pilgrimage to Jerusalem and the Holy Land, 1187-1291, (Crusade Texts in Translation, 23), Farnham: Ashgate, 2012, pp. 48-49. For Burchard's description of his method of dividing the Holy Land to geographical units, see Laurent (ed.), Peregrinatores, p. 21. The text provided in MS London (fol. 2r) and in MS Zwickau (fol. 113v) is essentially the same.

15 Laurent (ed.), Peregrinatores, p. 90. 
and with the structure of the text's earlier sections. ${ }^{16}$ This is reflected by the comment that bridges between his extensive comments on Armenia and the brief description of his journey to Egypt:

Multa alia vidi et perambulavi in terra illa que per omnia scribere longum esset. Steti autem hac ultima vice apud regem a festo Iohannis ante portam lat[inam $]^{17}$ usque in crastinum Margarete ${ }^{18}$ et sic redii in Aycium civitatem maritimam, et ascensa navi processi iuxta Mamistram in Mallotam civitatem opinatissimam, de qua legitur in Iudith, et inde per Adenam et Tharsum Cilicie veni Kurcum ubi habundat crocus bonus. De Curco veni Seleuciam Maritimam que est in Capadocia, transitaque Capodocea navigavi Cyprum et applicui Salomine. Peractis negociis apud regem Cypri navigavi in Syriam. Veni Thyrum et inde Ptholomaidem transactis 7 ebdomadibus postquam de Armenia navigavi. In kalendis Septembris ascensa galea ut navigarem in Egiptum de Ptholomaide veni ad montem Carmeli in Caypham inde Dothan que nunc Castrum Peregrinorum dicitur, inde Cesaream Palestine. ${ }^{19}$

Providing the dates of Burchard's stay in Armenia as well as his itinerary toward Egypt, this comment epitomizes the shift from a systematic description of the Holy Land to a travelogue. Furthermore, this comment also reveals that Burchard updated his work, at least occasionally, as time went by. This is confirmed by the

16 For Burchard's initial commitment to restrict his text to the Holy Land, see Laurent (ed.), Peregrinatores, p. 31: 'Distat autem locus iste [Valania] ab acconensi civitate per VIII dietas [....] et licet ultra processi in terra ista eam contemplando, tamen de ea nichil scribo, quia non propono de aliis terris scribere aliquid, nisi de terra sancta.' This comment appears in slight changes in MS London, fols 7v-8r; MS Zwickau provides a somewhat different text: 'Distat autem locus ille a civitate Achonense per 8 dietas, de Ierusalem vero per 15 dietas [....] et licet multum ultra processerim versus Gurgiam que olim Capadocia dicebatur et Armeniam et Syciliam tamen de terris illis nichil scribo quia tota mea intencio versatur circa descripcionem terre sancte' (fols $118 \mathrm{r}-118 \mathrm{v})$.

17 May 6.

18 The feast of St. Margaret is July 20. Placed within the sequence of dates provided by Burchard, it becomes clear that he refers here to 1284; see Rubin, 'Burchard', p. 181.

19 Rubin, 'Burchard', p. 183: ['I travelled through that country and saw there many other things which would have been too long to fully put in writing. This last time I stayed with the king from the feast of John before the Latin Gate to the day following the feast of Saint Margaret [ 6 May-21 July] and thus returned to Ayas, the maritime city, and, having embarked a ship proceeded by Mopsuestia to Mallos the illustrious city, about which we read in Judith, and from there through Adana and Tarsus of Cilicia I reached Corycos where good crocus abounds. From Corycos I came to maritime Seleucia which is in Cappadocia, and having crossed Cappadocia I sailed to Cyprus and landed in Salamis. Having completed my business with the king of Cyprus I sailed to Syria. I came to Tyre and from there to Acre seven weeks after I had sailed from Armenia. On the first of September, having embarked a ship so that I would sail to Egypt, I went from Acre to Mount Carmel, to Haifa and from there to Dothan which is now called Castrum peregrinorum [mod. 'Atlit] and from there to Caesarea of Palestine.'] Laurent's text is far less detailed here, notably omitting the dates. Laurent (ed.), Peregrinatores, p. 93. 
fact that the London text mentions another visit to Armenia which took place during the summer of $1285 .{ }^{20}$ The expression 'ultima vice' ('last time') in the above-quoted phrase therefore indicates that these words must have been written before that later visit, and thus serves as evidence that the complete version of the Descriptio represented by the London/Zwickau text should be read at least partly as a notebook into which Burchard kept adding materials as time went by.

The notebook quality of the part of the Descriptio which follows the account of Armenia is evident in the Egyptian section of Burchard's work. It is this characteristic of his text that explains why, for example, the author discusses local Christianity (Appendix 1, 11. 85-89), leaves this subject in order to discuss a range of other themes, finally returning to this topic (Appendix 1, 11. 150-156) providing further, but also contradictory, information. Thus, in the first discussion he says that he had heard from Christians and Muslims that there were more than 300,000 Christians in Egypt, but in the second he speaks of over $600,000 .{ }^{21}$ Perhaps more significantly, only in his second discussion of local Christians does Burchard refer to the extreme pressure exerted on them to convert. Given the similarity in the wording employed in the two discussionswhich makes it difficult to argue that one of them reflects a later interpolation rather than Burchard's own text-the best explanation for this is that, as Burchard continued his journey in Egypt, he accumulated additional information concerning Egypt's Christian community, which he then added into his notebook. A similar phenomenon can be noted with regard to Burchard's comments on the pyramids: having mentioned them briefly in the context of his description of the Nile (Appendix 1, 1l. 64-66), Burchard returns to them, this time in a more elaborate manner, toward the end of his account of Egypt (Appendix 1, 1l. 187193). Such examples can be multiplied, so that one can safely conclude that beginning with his discussion of Armenia, Burchard's Descriptio ceases to be a planned portrayal of a specific territory and begins to resemble a travelogue, at least occasionally updated as its author continues his travels. ${ }^{22}$

It is noteworthy that while Burchard's manner of working took a clear turn between his discussion of the Holy Land and his account of Egypt, the attitudes guiding him remained much the same. His portrayal of the Nile reveals a perspective similar to that which characterizes his depiction of the Holy Land: an attempt to provide a complete picture of a geographical unit rather than a linear portrayal of the sites and geographical elements which he actually saw. In that, Burchard's Egyptian unit differs, for example, from the accounts of Egypt penned

\footnotetext{
Rubin, 'Burchard', pp. 181, 189-90.

For the second figure, I rely on the reading provided by MS Zwickau. See Appendix 1, 1. 152.

22 It is, of course, possible that Burchard meant to later edit this section and was unable to do so, or, alternatively, that such an edited version exists but has not yet been discovered.
} 
by authors such as Burchard of Strasbourg, who wrote about a century earlier, or William of Boldensele, who wrote several decades later. Both of these authors were certainly curious about the Nile, but neither of them made an attempt of the sort Burchard did to provide a comprehensive picture of the Nile's various branches (Appendix 1, 1l. 37-64). ${ }^{23}$ Burchard of Mount Sion's relatively critical outlook, which characterizes his account of the Holy Land, is also revealed in his discussion of the origins of the Nile, as he chooses to leave this as an unresolved question rather than to repeat the widely held belief that the river comes out of paradise. $^{24}$

Given the fact that, as we have seen, Burchard composed his account of Egypt while traveling, adding information as he advanced, it is more expedient, in order to gain an understanding of its contents, to look at the main kinds of data it provides than to follow its narrative. These can be described as follows:

1. Itinerary: the text provides, though in a partial and at times only implicit manner, a picture of Burchard's movements through Egypt. Burchard left the Holy Land at the coastal al-Darum. From there he went to Al-'Arish, Ras Karum and Farama (Pelusium). From there he went to Tinnis and from there to Damietta. From Damietta, Burchard traveled toward Cairo through Miniet abu-Abdallah, Mansura and Sammanud. Having visited Heliopolis, he went further south to Cairo and to the pyramids at Giza. Burchard also visited the balsam garden, but it is unclear at what stage of his journey he did that, and was also taken to a sort of zoo the location of which is not provided by the text. From Egypt Burchard travelled to Sicily but he offers no information as to his route from Cairo back to the Mediterranean. It is improbable that he traveled through the western part of the Delta, his knowledge of it being considerably inferior to that of its eastern part. It is also very difficult to believe that had he visited Alexandria he would not have provided his readers with at least some comments about it.

23 Burchard of Strassburg, Itinerarium, pp. 64-67; Carl L. Grotefend, Die Edelherren von Boldensele oder Boldensen, Hannover: Hofbuchdruckerei der Gebr. Jänecke, 1855, pp. 36-44 [referred to below as 'Boldensele, Itinerarius'].

24 For several examples of authors writing that the Nile originated in paradise, see Burchard of Strassbourg, Itinerarium, p. 66; Boldensele, Itinerarius, p. 39; Jacopo da Verona provides further evidence for the uniqueness of Burchard's perspective as he says nothing of the Nile's branches, and refers to it as one of the four rivers of paradise. Pellegrinaggio ai luoghi santi: Liber peregrinationis di Jacopo da Verona, intr. and trans. Vittorio Castagna, ed. Ugo Monneret de Villard, Verona: Accademia di agricoltura, scienze e lettere, 1990, p. 280. Notably, this notion survived well into the sixteenth century. Benjamin Arbel, 'Renaissance Geographical Literature and the Nile', in Haggai Erlich and Israel Gershoni (eds), The Nile: Histories, Cultures, Myths, London: Lynne Rienner, 2000, p. 109. 
2. Egypt's Population: Burchard presents his readers with considerable information concerning Egypt's inhabitants. He is concerned, first and foremost, with the country's Christians, providing, as was already noted, different estimates as to their number in two places in this section. $\mathrm{He}$ also refers to the great number of churches on the one hand and to the persecutions to which these communities are subject on the other. But Burchard is also interested in Egypt's non-Christian populations. In this context he describes the division between Bedouins, Saracens and Turks. Interestingly, he thought that the Bedouins are more numerous than the members of the other groups, and that while the Saracens rule the country, the Turks are superior as the sultans come from their ranks and they make better soldiers. He was also impressed with the country's great population.

3. Geographical Information: much of Burchard's text is devoted to various aspects of Egypt's geography. Firstly, a considerable part of the text is devoted to Burchard's attempt to describe the Nile's branches. But his geographical interests were not limited to the Nile, and he also discusses Egypt's size and shape, names the regions bordering it, provides distances between various sites in it and enumerates its ports.

4. Biblical Geography of Egypt: in his description of Egypt, Burchard refers to several sites as connected to biblical traditions. Of central importance in this respect are locations considered to be related to the Exodus of the Hebrews, and to Mary and Christ's flight to Egypt. It is noteworthy, however, that in contrast to the part of the Descriptio which is devoted to the Holy Land, these sites do not take a central position in Burchard's account of Egypt.

5. Egypt's Economy: Burchard shares with his readers considerable information concerning substances which can be found in Egypt and comments also about those which cannot be found there and for which Egypt is dependent on import from other regions. Timber for the construction of boats is particularly significant in this context, as are also various metals. The difficulty of finding stones suitable for building houses brings Burchard to also characterize local structures.

6. Mirabilia: Burchard included in his description of Egypt several discussions of wonderful things he saw there. These include the pyramids, animals that he saw in a zoo he visited (particularly, the giraffe, which he had never seen before), the balm garden at Heliopolis and a festival, led by the sultan, in which the relics of Saint John are said to have played a central role. 


\section{Written Sources and Cultural Context}

In describing the Holy Land, Burchard was working within an established Latin tradition, and, as was already mentioned, following a clear, systematic, plan. He is also likely to have sat down to compose this text having developed at least a general picture of what he intended to include in it. Furthermore, as he used for his work on this part of his project a considerable number of texts, ${ }^{25}$ one may assume that he was working in, or within reach of, a library, plausibly that of one of Outremer's Dominican convents. ${ }^{26}$ With Egypt, the circumstances were very different. Firstly, while it is possible that there circulated at the time accounts of Egypt which have not reached us, the number of Latin texts describing that region which were available in the 1280s must have been much more limited than that of descriptions of the Holy Land. Secondly, as we have seen above, Burchard seems to have composed this section while travelling, so that books would have been much less accessible to him. Indeed, while it is difficult to prove that he made use of no text at all, several indications point in this direction. Firstly, his account of the Nile's branches does not closely resemble any of those studied by Cooper. ${ }^{27}$ The fact that Burchard's description of the Delta's eastern part, which he in fact visited, is much better than that of the West further supports the hypothesis that his knowledge of the Nile is based on personal observation and on contacts with people he met on his way. Secondly, while Burchard mentions Jacques de Vitry's work as a major source for his description of the Holy Land, ${ }^{28}$ a comparison between Burchard and Jacques de Vitry's accounts of, for example, the balsam garden or Farama shows that these are unrelated..$^{29}$ Arabic accounts, which, theoretically at least, would have been much more useful for Burchard, are unlikely to have been accessible to him, since it is improbable that he was able to read Arabic..$^{30}$ That he did not use Arabic sources is confirmed by the fact that a very limited number of Arabic place names appear in the text.

While there is no evidence that Burchard used specific texts as he was working on his account of Egypt, some pieces of information included in it must have originated in Latin works which Burchard had consulted earlier in his life.

\footnotetext{
Pringle, Pilgrimage, p. 50.

Evidence in support of this hypothesis is presented below.

Copper, The Medieval Nile, pp. 265-277.

Laurent (ed.), Peregrinatores, p. 23.

Jacques de Vitry, Histoire orientale, ed. and trans. Jean Donnadieu, Turnhout: Brepols, 2008, pp. 194, 346.

30 MS Zwickau, fol. 113v provides a comment with regard to Burchard's use of translators, which makes it likely that he knew very little, or no Arabic at all: 'a Syris vel a Sarracenis et aliis terre ipsius habitatoribus quos ductores et interpretes frequenter mecum habui diligentissime de omnibus investigans.'
} 
Such is, for example, Burchard's mention of the Theban Legion, probably based on one of the texts recounting the martyrdom of this renowned Roman army unit. ${ }^{31}$ It is particularly likely that Burchard's comment in this regard is founded on William of Tyre's Chronicon, where the toponym Thebes is tied to a region neighboring Cairo on the one hand and to the famous Roman legion on the other. ${ }^{32}$ Burchard's notion that the Nile has seven branches probably also goes back to earlier texts: this was a very common idea which appears in Western literature since ancient times and which was shared by authors much closer to Burchard in time, such as William of Tyre and Joinville. ${ }^{33}$ The confusion between Bilbeis and Pelusium seems to also belong to this category, as it appears in earlier Latin works. ${ }^{34}$ Burchard's reference to the unique astronomic attributes of Meroe and Aswan (Appendix 1, 1l. 69-71) points to the same direction. Comparing it with its most likely sources, it is evident that it is corrupt. ${ }^{35}$ This may be the result of difficulties in the transmission of the Descriptio, but it is probably at least partly due to the fact that Burchard wrote these comments out of memory rather than consulting a written work.

31 For an early version of this story, see Eucherius of Lyon, Passio Acaunensium martyrum, ed. Bruno Krusch, (Monumenta Germaniae Historica, Scriptores rerum Merovingicarum, 3), Hannover: Hahnianus, 1896, pp. 20-41. Another version of this appears in: Ernst Dümmler, 'Sigebert's von Gembloux Passio sanctae Luciae virginis und Passio sanctorum Thebeorum', Abhandlungen der Königlichen Akademie der Wissenschaften zu Berlin, Berlin: Realschul-Buchhandlung, 1893, vol. II, pp. 210-219.

32 Willelmus Tyrensis, Chronicon, ed. Robert B. C. Huygens, (Corpus Christianorum Continuatio Mediaevalis, 63, 63a), Turnhout: Brepols, 1986, vol. II, p. 897: 'Nos autem, antiquum eius vocabulum non tenentes, opinamur priscis temporibus Thebaidam dictam, unde sanctorum Thebeorum legio, que sub Diocletiano et Maximiano Augustis apud Agauno martyrio coronata est, fuisse dicitur, cuius primicerius magnus martyr Mauricius legitur fuisse.'

33 Cooper, The Medieval Nile, pp. 30, 35 and elsewhere; Joinville, Vie, pp. 92-93; Willelmus, Chronicon, vol. II, pp. 894-895, though note that William thought this view was erroneous.

34 Willelmus, Chronicon, vol. II, p. 883; Jacques de Vitry, Histoire orientale, p. 194.

35 The closest parallel passages I have been able to identify are these: 'Simili modo tradunt in Syene oppido [...] solstiti die medio nullam umbram iaci [...] constatque in Berenice urbe Trogodytarum, et inde stadiis quattuor milibus DCCCXX in eadem gente Ptolemaide oppido [...] hoc idem ante solstitium quadragenis quinis diebus totidemque postea fieri, et per eos XC dies in meridiem umbras iaci. Rursus in Meroe [...] bis anno absumi umbras, sole duodevicesimam tauri partem et quartamdecimam leonis tunc obtinente' (Pliny, Natural History, ed. and trans. Harris Rackham, Loeb Classical Library, London: William Heinemann, 1958, vol. I, p. 316); 'In Syene solsticiali die medio nulla fit umbra [...] Apud Trogoditas xlv diebus ante solsticium, et totidem postea, umbra penitus absumitur, et his xc diebus umbra in meridiem iacitur. In Meroe, insula Nili, bis in anno absumitur umbra, cum sol est in xii parte Tauri et in xiiii Leonis' (Valerie I. J. Flint [ed.], 'Honorius Augustodunensis, Imago mundi', Archives d'Histoire Doctrinale et Littéraire du Moyen Age 49 [1982], p. 97). Bede provides a text which is somewhat further removed. See Beda Venerabilis, De natura rerum liber, ed. Charles W. Jones and Frances R. Lipp, (Corpus Christianorum Series Latina, 123a), Turnhout: Brepols, 1975, pp. 231-232. 
While it is questionable whether Burchard used written sources in his Egyptian section, it is clear that this part of his work relied, to a considerable extent, on oral exchanges he had with members of various cultural groups that he encountered. This is made clear by numerous explicit references in the text to such exchanges (Appendix 1, 1l. 85-87, 114, 150-151, 157, 160-161, 182).

The discovery of the London and Zwickau manuscripts, both of which shed significant new light on Burchard's career, also enables us to place him more firmly within a cultural or intellectual context. In particular, they present evidence that his connection to Outremer was much deeper than that of a standard pilgrim, providing clear indications that Burchard's sojourn in this territory spread over a considerable period of time ${ }^{36}$ and that he was personally acquainted with major figures in the kingdom such as both the Latin and Greek patriarchs of Jerusalem. ${ }^{37}$ Terms he employs also suggest that he was deeply influenced by the Frankish culture that developed in the kingdom of Jerusalem. Firstly, in his description of the Holy Land, he frequently uses leuca, a term typical of Frankish Outremer, as a unit of distance. ${ }^{38}$ Similarly, he employed the word bercile, which is a Latinized form of the Arabic word for pool (بركة), used by the Franks of Outremer. ${ }^{39}$ Burchard's connection to the kingdom's culture also settles very well with the above-presented hypothesis that as he travelled in Egypt he recalled information from William of Tyre's Chronicon. More evidence for Burchard's ties to Outremer is possibly provided by the Zwickau manuscript: ${ }^{40}$

Verum, ego frater Burcardus ordinis fratrum predicatorum, videns quosdam affici desiderio ea saltem aliqualiter ymaginari, que non possunt presentialiter intueri, et cupiens eorum desiderio satisfacere quantum possum, ipsam terram, quam pedibus meis pluries pertransivi et [quam] per $\mathrm{x}$ annos, quibus

36 Rubin, 'Burchard', p. 181.

37 Ibid., p. 179.

38 Emmanuelle Vagnon, Cartographie et représentations de l'Orient méditerranéen en Occident: du milieu $d u$ XIIIe à la fin du XV siècle, Turnhout: Brepols, 2013, p. 107, n. 35. It is noteworthy that in the Egyptian section things are more complex as miliare appears more frequently than leuca (10 and 6 times respectively, in addition to one mention of miliaria teutonica). This may be the result of exchanges Burchard had, during his travels in Egypt, with Italians who would have preferred miliare. For such contacts see below, Appendix 1, 11. 160-161 and 179-182.

39 Laurent (ed.), Peregrinatores, pp. 33, 67; Laura Minervini, 'Les emprunts arabes et grecs dans le lexique français d'Orient (XIIIe-XIVe siècles)', Revue de linguistique romane 301-302 (Janvier-Juin 2012), p. 111.

40 MS Zwickau, fol. 113v: ['Truly, I brother Burchard of the Order of Preachers, seeing that some people are affected by a desire to picture for themselves in some degree at least those things that they are unable to look upon face to face, and wanting to satisfy their wish as far as I can, have both recorded and studiously described that land through which I have frequently passed on foot and which I have diligently inspected in so far as I have been able during the ten years in which I was a brother of that province.'] 
frater provincie illius fui, quantum potui consideravi diligenter, et notavi et studiose descripsi.

Most of this paragraph appears also in the London manuscript, but the crucial words 'et [quam] per $\mathrm{x}$ annos, quibus frater provincie illius fui' are unique to the Zwickau manuscript. ${ }^{41}$ If it is indeed trustworthy, Burchard should be seen a longtime member of the Dominican province of the Holy Land, and firmly placed within Outremer's intellectual milieus. But, as we have seen, even if one disregards these phrases, the extant evidence clearly shows that Burchard was strongly related to the Holy Land and, in all likelihood, to its Dominican province.

Bearing in mind that Burchard was at least partly working within the intellectual environment which developed in Frankish Outremer, it becomes easier to contextualize his account of Egypt. Firstly, as we have seen, the notion that Christians are very numerous in Egypt is repeated twice in this section. This claim should probably be connected to the argument which, as was already noted, Burchard makes at the beginning of his discussion of Armenia, according to which the population of the East is mostly Christian. But this line of thought is not Burchard's innovation. Writing several decades earlier, Jacques de Vitry, Acre's renowned bishop, made a similar argument. ${ }^{42}$ Furthermore, Burchard's own comments also imply that the question of whether or not Christians made the majority among the inhabitants of the East was discussed at the time, since he argues that while some disagree with his view others support it. ${ }^{43}$ Additionally, one may assume that information-of varying levels of accuracyconcerning the population of the East circulated in places such as Acre which was, at the time, an important gateway for Westerners traveling into Asia. That the East was mainly Christian may have also been an important notion for the Franks of Outremer in view of their continuing inability to effectively face Mamluk military power, as it would have possibly provided them with a reason for optimism.

Burchard also treats, in his account of Egypt, an additional subject which was central in the discourse of the kingdom of Jerusalem. This is the assistance provided to the Mamluks by Western merchants. In two places in his account of Egypt, Burchard mentions substances which are not found in Egypt and argues

41 Cf. MS London, fol. 2 r.

42 Jacques de Vitry, Lettres, p. 576. In another place Jacques argues that even in Egypt there are more Christians than Muslims. Jacques de Vitry, Lettres, p. 585.

43 MS London, fol. 39r: 'Sciendum autem quod in rei veritate licet quidam aliter senciant qui parum vel nichil sciunt quid loquantur quod oriens totus ultra mare usque Indiam et Ethiopiam omnino nomen Christi confitetur et predicat [...] ita quod pro certo assero sicut per memeth ipsum vidi et $a b$ aliis quibus note erant omnes regiones audivi quod semper pro uno Sarraceno 30 Christianos poteris estimare in omni loco et regione preterquam in Egipto et Arabia...' Cf. Laurent (ed.), Peregrinatores, p. 90. 
that if Western merchants would cease to bring them there, Egypt would no longer be able to sustain itself (Appendix 1, ll. 163-170; 178-182]. These comments should be understood as a part of a much wider discourse on the support provided by Latin merchants to Outremer's Muslim foes. One aspect of the Latin engagement with this issue is the recurrent papal bans against such commercial activities, but it is also clear that this was a subject often discussed in places such as Acre which, on the one hand, saw a great number of merchants and, on the other, was very vulnerable to Mamluk attacks. ${ }^{44}$ Evidence for this is provided by the discussion of these commercial ties by Fidenzio of Padova, who had spent a long time in the city before returning to the West where he completed, shortly before the final fall of the kingdom of Jerusalem, a text titled Liber recuperationis Terre Sancte. ${ }^{45}$

Burchard's strong connection to the intellectual milieus in the kingdom of Jerusalem can perhaps also help to contextualize the complex nature of his work, and, in particular, his shift from the composition of a systematic description of the Holy Land to the writing of a travelogue documenting a journey through a range of other territories. This shift epitomizes what has been referred to as the ultimate relocation of the paradigm of travel from the ideal of pilgrimage to those of empirical curiosity and practical science' and dated to $1250-1450 .{ }^{46} \mathrm{In}$ other words, Burchard's decision to neglect his initial commitment to discuss in his work only the Holy Land and to provide his readers with abundant information concerning other regions resulted in the production of a text which captures the precise moment of such a move by an individual author. But how can one explain this radical change in Burchard's perception of his own work? It is likely that it was in Outremer that Burchard became exposed to this new inclination: one of the most prominent pioneers of the new trend was none other than William of Rubruck, who composed his Itinerarium in 1255 while teaching in Acre's Franciscan convent. The Itinerarium, like the part of the Descriptio that follows the section on Armenia, includes descriptions of territories through which its author traveled providing ample geographical and ethnographic information. Furthermore, like Burchard, William kept updating his work as he

44 For a general discussion of these bans, see Sophia Menache, 'Papal Attempts at a Commercial Boycott of the Muslims in the Crusader Period', Journal of Ecclesiastical History 63/2 (April 2013), pp. 236-259.

45 For this text, see Fidentius de Padua, Liber recuperationis terre sancte, in Girolamo Golubovich, Biblioteca Bio-Bibliografica della Terra Santa e dell'Oriente francescano, 5 vols, Florence: Collegio di S. Bonaventura, 1913, vol. II, pp. 1-60. For references to his treatment of Western commercial ties with the Mamluks, see Sylvia Schein, Fideles crucis: The Papacy, the West and the Recovery of the Holy Land, 1274-1314, Oxford: Clarendon Press, 1991, pp. 95, 98-99.

46 Jaś Elsner and Joan-Pau Rubiés, 'Introduction', in Jaś Elsner and Joan-Pau Rubiés (eds), Voyages and Visions: Towards a Cultural History of Travel, London: Reaktion Books, 1999, p. 31. 
advanced ${ }^{47}$ It seems likely that a pathbreaking project such as William's would have left a mark on Acre's culture for a long time, and that Burchard would have become aware of it as he worked in the city during the 1280s. Additionally, even if he would not have known William's work, Burchard is likely to have encountered in the kingdom of Jerusalem other texts which share this new trend. Burchard of Strasbourg's above-mentioned description of Egypt should, for example, also be tied to this new literary tradition and is very likely to have been available in Acre. ${ }^{48}$ Thus, it is very likely that at least some of the notions which drove Burchard to continue writing as he traveled out of the Holy Land were related to the works of earlier authors which he encountered in the kingdom of Jerusalem.

\section{The Egyptian Section and the Descriptio's Manuscript Tradition}

While, as was already noted, a survey of all extant manuscripts of the Descriptio remains a desideratum which lays outside the scope of the present article, a preliminary survey of twenty of them does enable us to make some conclusions with regard to the manuscript reception of the Egyptian section..$^{49}$ As we shall soon see, the conclusions of this partial survey are significant not only with regard to the way in which this section was treated by scribes/editors working on manuscripts of the Descriptio but also for the future reconstruction of this work's transmission history.

At the current state of research, it is possible to identify three groups of manuscripts which reveal different treatments of Burchard's account of Egypt. One group, which, as far as one can presently tell, includes only the two abovementioned manuscripts (London, British Library, Add. 18929 and Zwickau, Ratsschulbibliothek, 1.12.5), provides the complete Egyptian section and, as stated in the beginning of this article, forms the basis for the discussion above, as well as for the edited text in Appendix 1.

47 Guglielmo di Rubruk, Viaggio in Mongolia, ed. and trans. Paolo Chiesa, Milan: Mondadori, 2011. Reaching Acre, William settled down to edit his work into the form in which he sent it to Louis IX and in which it reached us. Guglielmo di Rubruk, Viaggio, pp. XLII-XLV, 316.

48 That this text was available in Acre is supported by the fact that from an early stage a description of Egypt, clearly based on Burchard of Strasbourg's text, circulated with a report, written in Acre at the request of Pope Innocent III, by Raoul de Mérecourt, patriarch of Jerusalem, and the masters of the Hospitaller and Templar knights. See, for example, Prague, National Library, XIV C 16, fols 23r-25r; Jacques Bongars (ed.), Gesta Dei per Francos, 2 vols, Hanau: Typis Wechelianis, apud heredes I. Aubrii, 1611, vol. I, pp. 1125-1129.

49 For the existing lists of the manuscripts of the Descriptio, see above, n. 13. 
A second group includes manuscripts which end at the point in which the text provided by Laurent does: ${ }^{50}$

Inde veni Damiatam, que antiquitus Memphis dicitur. Hec est terra Yesse, in qua olim filii Israel morabantur, Pharaoni in luto et latere servientes. In hac eciam postea lapidatus est Ieremias.

Reading these phrases, it becomes clear that this cannot have been the way Burchard planned to complete his elaborate, systematic and well-ordered text. It ends much too abruptly, with Damietta reached and mentioned but not described and with no concluding remarks made. The slight variations occurring between textual witnesses ending at this point are instructive in this regard. Some scribes who produced a text ending at this point clearly felt that something was missing in the text they copied. Thus, for example, a manuscript now in Lilienfeld, adds at this point the words 'non plus inveni' ('I found no more'). ${ }^{51}$ Additionally, the very last phrases appearing in several manuscripts suggest that some scribes actually had before them a text that went on for at least several additional words which, gradually becoming unintelligible, were omitted. Thus a manuscript now in Prague adds at this point the words 'et sic ista sufficiant' ('and thus these shall suffice') which implies that the copy used by this scribe went further on.$^{52}$ The final text of a manuscript now in Zwettl reads 'Dothapius nevus[?] in Memphis et inde', which is probably a corruption of 'De Taphnis [Tinnis] venimus in Memphis' ('from Tinnis we came to Memphis'). ${ }^{3}$

A third group provides a text of the Descriptio which closes with an account of Egypt, albeit one which is much shorter than that provided by the London/Zwickau text. The description of Egypt transmitted by this group, to which we shall refer as the 'abbreviated version', is important since, as we shall soon see, it enjoyed a considerable reception, a fate not shared by the complete Egyptian account, and because its analysis sheds light on the transmission of the Descriptio.

Before we examine the contents of the abbreviated section, it would be expedient to compare the beginning of this redaction with the parallel text in the London/Zwickau redaction:

50 Laurent (ed.), Peregrinatores, p. 94. For an English translation, see Pringle, Pilgrimage, p. 320: 'From there I came to Damietta, which in antiquity was called Memphis. This is the land of Jesse, in which the children of Israel once dwelt, serving Pharaoh in mortar and brick. In it Jeremiah was also later stoned.'

51 MS Lilienfeld, Monastery Library, 145, fol. 192r. MS Vienna, National Library, 3341, fol. 15v, similarly ends with the words 'non inveni plus'.

52 MS Prague, National Library, XIV C 16, fol. 56v.

53 MS Zwettl, Zisterzienserstift, Cod. 76, fols 225v-256r. A very similar phrase is provided by MS Klagenfurt, Universitätsbibliothek, Pap. -Hs. 152, fol. 46v. 
A Missing Link in European Travel Literature

\begin{tabular}{|c|c|}
\hline MS London, fol. $42 r^{54}$ & $\begin{array}{c}\text { Vatican Urb. lat. } 393 \text { [referred to below as } \\
\text { MS Vatican], fol. } 15 r^{55}\end{array}$ \\
\hline $\begin{array}{l}\text { In kalendis Septembris ascensa galea ut } \\
\text { navigarem in Egiptum de Ptholomaide veni } \\
\text { ad montem Carmeli in Caypham, inde } \\
\text { Dothan que nunc Castrum Peregrinorum } \\
\text { dicitur, inde Cesaream Palestine. IInde } \\
\text { navigavi] per Antypatridem et Ioppem et } \\
\text { Iamniam, per Azotum et Ascolonem, per } \\
\text { Gazam et Dorre, que est principium } \\
\text { solitudinis, et inde ad gulfum Larisse, ubi } \\
\text { est primus portus Iudee. De gulfo isto in } \\
\text { Rasencasse, que est prima civitas Egipti in } \\
\text { solitudine Pharan, et inde Pharamiam } \\
\text { civitatem pulcram et munitam, sed non } \\
\text { habitat in ea homo quia serpentes eiectis } \\
\text { habitatoribus eam penitus possederunt. }\end{array}$ & $\begin{array}{l}\text { Et } \text { post }^{56} \text { dies aliquot inde navigans per } \\
\text { littus Palestine sive Phylistim pertransivi } \\
\text { Caypham, montem Carmeli, Doram, } \\
\text { Cesaream Palestine, Antipatridam, Ioppen, } \\
\text { Iamniam, Accaron, Azotum, }{ }^{57} \text { Ascalonem, } \\
\text { Gazam, descitum }{ }^{58} \text { totum }^{59} \text { arenosum }^{60}\end{array}$ \\
\hline
\end{tabular}

54 'On the first of September, having embarked a ship so that I would sail to Egypt, I went from Acre to Mount Carmel to Haifa and from there to Dothan which is now called Castrum Peregrinorum [mod. 'Atlit] and from there to Caesarea of Palestine. From there I sailed through Antipatris and Jaffa and Yibna, through Ashdod and Ascalon, through Gaza and Al-Darum [?] which is the beginning of the desert and from there to the gulf of Al-'Arish where the first port of Judea is. From that gulf to Ras Kasrum which is the first city in Egypt in the desert of Pharan and from there to Farama, the beautiful fortified city, but no man lives in it because, its inhabitants having been driven out, snakes completely occupied it.' For the variants in MS Zwickau, and for the identification of the various sites mentioned, see the text in Appendix 1.

55 I provide variants from MSS Oxford, Bodleian Library, Lat. Hist. e. 1, fols 29v-30r; Paris, Bibliothèque nationale de France, Nouv. acq. lat. 288, fol. 42r; Philadelphia, UPenn Ms. Codex 60, fol. 40r. Orthographic variations were generally ignored. These manuscripts are referred to below respectively as MSS O, BnF and Ph: ['And after several days, sailing from there along the coast of Palestine or Philistim, I passed through Haifa, Mount Carmel, Dora, Caesarea of Palestine, Antipatris, Jaffa, Yibna, Accaron, Ashdod, Ascalon, Gaza [and] all of the sandy desert as far as the mouths of the Nile river where the city Farama, indeed walled and well built, is located. But no one lives in it because snakes occupied it completely.'] per BnF

Azotum om. Ph

58 desertum, $\mathrm{BnF}, \mathrm{O}, \mathrm{Ph}$

59 totum om. O, Ph

${ }_{60} \mathrm{O}$ inserts here what is clearly a misplaced titulus: 'De officio misse orientalis'. Ph has a more appropriate titulus: 'De descriptio [sic] terre Egypti'.

61 Perveni usque O; Perveni denique usque $\mathrm{Ph}$

62 munita $\mathrm{O}, \mathrm{Ph}$

63 hedifica BnF

64 non est ibi O

65 possederunt $\mathrm{BnF}, \mathrm{O}, \mathrm{Ph}$ 
Comparing the texts, it becomes clear that the London/Zwickau version is more complete and, in all likelihood, closer to the original. The text provided by the abbreviated version results from the work of an editor who was both less interested in Burchard's personal story, thus omitting the date of his journey to Egypt, and less knowledgeable about the geography of the Levant, thus leaving out the reference to Al-'Arish and Ras Kasrum. That two of the kingdom of Jerusalem's most important sites, Acre (Ptolemais) and 'Atlit (Castrum Peregrinorum), are not mentioned in the text provided by the abbreviated version may imply that the editor was not familiar with the late thirteenthcentury Eastern Mediterranean and, also, perhaps, that he was working after the kingdom's fall in 1291. In any case, it is extremely unlikely that Burchard himself, who constructed his description of the Holy Land around Acre, would have omitted it from a discussion of his travel along the coast. It is thus most probable that the account of Egypt, as provided by the abbreviated version, represents a reedited text based on the London/Zwickau redaction.

It is worthwhile to compare these two paragraphs also to the text provided by Laurent's edition at this point: ${ }^{66}$

Inde navigavi in Syriam et veni Tyrum, et post dies aliquot inde navigans per littus Palestine seu Philistiim pertransivi Caypham, montem Carmelum, Doram, Cesaream Palestine, Antipatridam, Ioppen, Iamniam, Accaron, Azotum, Ascalonem, Gazam, desertum totum arenosum usque ad ostia Nili fluminis. Inde veni Damiatam...

This paragraph shares with the abbreviated version the omission of Acre and 'Atlit as well as Al-'Arish. It is thus likely that the text presented in Laurent's edition is dependent on that provided by the manuscripts of the abbreviated version. This conclusion may be applicable to the whole of the Descriptio and should thus be taken into account in any future attempt to reconstruct the text and its tradition.

What are the contents of this section? Following the opening paragraph cited above, the abbreviated version follows the text provided by the London/Zwickau redaction, with minor variants, up to the subsection which deals with the balsam garden. Here, with the words 'et quia fons iste modicus est' ('and because that spring is small'), the two traditions again separate, with the abbreviated version

66 Laurent (ed.), Peregrinatores, pp. 93-94. For an English translation, see Pringle, Pilgrimage, pp. 319-320: 'From there I sailed to Syria and came to Tyre; and after a few days, sailing from there along the coast of Palestine or of the Philistines passed by Hayfa, Mount Carmel, Dor, Caesarea of Palestine, Antipatris, Joppe, Yibna, Ekron, Ashdod, Ascalon, Gaza and the whole sand desert as far as the mouth of the Nile. From there I came to Damietta...'. 
providing four paragraphs which differ in significant ways from the parallel text in the London/Zwickau redaction.

The first of these four paragraphs (which are edited below in Appendix 2), in both the London/Zwickau text and in the abbreviated version, discusses the Muslim attempt to increase the amount of water available to watering the balsam garden. In both texts a well is dug from which bulls draw water. Through a canal the water is then led to the holy spring to be mixed with its water. By these means the water of the new, artificial well, acquires the original spring's unique ability to fertilize the garden. The abbreviated version text differs from that of London/Zwickau only in that it mentions a stage in which the Muslims thought that, as the well they dug was near the spring, its water would share the unique quality of the water originating from the holy spring. Only once they had seen that this was not the case, they dug a canal in order to have the water of the well mix with that provided by the original spring.

The second paragraph describes a miracle associated with the bulls drawing water from the well: these refuse to work between Saturday at noon and sunrise on Monday. This description does not appear in a complete form in the parallel place at the London/Zwickau section. Rather, a note appears here which refers to an earlier discussion of this miracle in the text: and indeed, this phenomenon is mentioned much earlier in Burchard's work, in the section devoted to Ein-Gedi. There he writes: ${ }^{67}$

Dixerunt mihi cultores orti quod boves qui trahunt aquam pro irrigando orto a meridie diei sabbati usque in diem lune numquam trahere volunt aquam propter celebritatem diei dominice etiam si conciderentur.

It is noteworthy that the wording of the Ein-Gedi passage and the Egyptian section with regard to this miracle is almost identical, which suggests that at some stage a scribe/editor working on the abbreviated version simply copied these words from the earlier part of the Descriptio. On the other hand, while in the Ein-Gedi section Burchard only attests that he was told about the miracle, the abbreviated version says that its author actually saw it (Appendix 2, 11. 13-14).

The third paragraph focuses on bathing in the holy spring. The author says that he bathed in it as do Christians and Muslims. He continues, saying that the Muslims have a terrible stench that can only be effaced by baptism and, in

67 MS London, fol. 22r: ['The cultivators of the garden told me that the bulls who draw water for the irrigation of the garden never wish to draw water, even if they would have been beaten to pieces, between Saturday at noon and Monday, because of the renown of Sunday.'] A very similar phrase appears in the discussion of Ein-Gedi in the above-mentioned Vatican manuscript (fol. 8r): 'Dixerunt mihi cultores orti quod boves qui trahunt aquam de fonte ipso a meridie sabbati usque ad diem lune nullo modo volunt aquam trahere etiam si in frustra conciderentur.' 
particular, baptism in that spring. However, he continues, while Muslims baptize their children and sometimes themselves there, that is not done in order to receive the benefits of the sacrament, but rather in order to get rid of the aforementioned odor. This paragraph has no parallel in the London/Zwickau text and one wonders whether it is indeed authentic. Perhaps it is related to Burchard of Strasbourg's account, as here we read that Muslims venerate the balsam garden spring and bathe in it. ${ }^{68}$

The fourth paragraph, which closes the text of the abbreviated version, describes a miracle which is narrated further down in the London/Zwickau redaction (Appendix 1, 1l. 142-149). Both texts describe an annual event, attended by Muslims, in which a chest containing relics related to Saint John is taken out of a church in Cairo and then carried several leucae downriver. Placed in the Nile's water, it is seen miraculously moving upstream to the place from which it was taken. The differences between the two texts are, however, noteworthy. While in the London/Zwickau text the aim of the placing of the chest in the Nile is to predict the river's inundation, in the abbreviated version, the purpose of the ceremony is to reveal whether the saint wishes to return to its original place. Further differences include the parties involved. Most notably, the London/Zwickau text mentions only Muslims as participants in this ceremony and argues that it is attended by the sultan himself, while the abbreviated version refers generally to Christians and Muslims as taking part in the ceremony and makes no mention of the sultan. It should also be noted that while in the London/Zwickau redaction this paragraph is separated from the discussion of the balsam garden by the description of the zoo, the abbreviated version omits the latter altogether so that the account of this miracle directly follows the paragraph concerning the bathing in the balsam garden spring.

These differences seem to support the hypothesis according to which the abbreviated version represents the work of an editor who reshaped Burchard's original work. ${ }^{69}$ Most notably, it is likely that while Burchard, who visited Egypt, and carefully studied the Nile, was aware of the great significance of its inundation for the country's inhabitants, this was completely alien, and of negligible meaning, for the later editor. Indeed, it is most likely that the ceremony which Burchard had in mind was related to the river's inundation: while I was unable to find sources which describe a celebration identical to that described by the London/Zwickau redaction, the closest available evidence, related to the Coptic festival of the martyr, is indeed connected to the great

8 Burchard of Strassbourg, Itinerarium, p. 65.

69 For simplicity's sake, we refer in the discussion below to one hypothetical scribe/editor. It should be noted, however, that the abbreviated version may well be the cumulative result of the work of several scribes/editors. 
river's flooding. ${ }^{70}$ Thus, the editor who produced the abbreviated version distanced the text from the reality of Egypt in the 1280s.

Perhaps more significantly, the editor who produced the abbreviated version of Burchard's account of Egypt thought that much of the material provided by the London/Zwickau text was of little interest and therefore stopped copying the manuscript he had before him in the midst of the account of that region, following the description of the miracle associated with the relics of Saint John. Not only did this editor thus abbreviate the portrayal of Egypt, but he also omitted everything that follows in the London/Zwickau text, including the description of Burchard's travels through Sicily and Italy and then back to the East. One can thus assume that this was an editor who was primarily interested in holy sites and miracles, and much less so in, for example, Egypt's economy, or in Burchard's comments on the volcanoes at the Tyrrhenian Sea.

\section{The Abbreviated Version: Reception and Circulation}

While the complete account of Egypt, as transmitted by the London and Zwickau manuscripts, seems to have been completely forgotten for centuries, the abbreviated version never disappeared from Western discourse. Firstly, it was extensively used by Marino Sanudo in his Liber secretorum fidelium crucis. In fact, much of the content of the chapter which appears under the title 'Continet dispositionem regni Aegypti' ('Includes the disposition of the Kingdom of Egypt'; book III, part xiv, ch. 12, pp. 259-262) is copied directly from Burchard's Egyptian section. This can be seen through phrases such as this: ${ }^{71}$

Tampnis fuit antiquitus civitas valde munita, et firmo loco sita, sed hodie omnino est destructa et pauci Beduini, propter pascua et terrae ubertatem, habitant in ruinis eius, et abundat piscibus et avibus supra modum.

Clearly, however, Sanudo did not have before him the complete version of Burchard's account of Egypt, but rather the abbreviated account. This can be seen through his discussion of the miracle associated with the relics of Saint John: ${ }^{72}$

70 See n. 35 in Appendix 1.

71 Bongars, Gesta, vol. II, p. 259, and cf. Appendix 1, 1l. 16-19. For an English translation of Sanudo's text, see Marino Sanudo Torsello, The Book of the Secrets of the Faithful of the Cross, trans. Peter Lock, Farnham: Ashgate, 2011, p. 413 [with slight emendations]: 'In ancient times Tampnis was a strongly fortified city, built on firm ground, but today it is totally destroyed and a few Bedouins live in the ruins for its pasture and the fruitfulness of the land. In addition, it abounds in fish and birds beyond measure...'.

72 Bongars, Gesta, vol. II, p. 260; cf. Appendix 1, 1l. 141-149; Appendix 2, 1l. 20-33. For an English translation, see Marino Sanudo, The Book of the Secrets, pp. 414-415 [with slight emendations]: 'In 
In Babylone quoque est miraculum memoria dignum: in monasterio enim ibidem constructo ad honorem beati Iohannis Baptistae est scrineum cum reliquiis eius...post celebrationem vero Missae scrineum in flumine ponunt, experiri volentes ubi Sanctus reliquias suas manere velit, in hoc videlicet loco an potius in priori...

The discussion of Egypt which Alonso Tostado, a fifteenth-century exegete, included in his commentary on Matthew also presents significant phrases and even paragraphs taken from Burchard's account of Egypt. Most notably, Tostado copied into his work the description of the balsam garden and that of the miracle associated with the relics of Saint John. ${ }^{73}$ Furthermore, Tostado explicitly refers to Burchard's work as a source he used. ${ }^{74}$ Looking at Tostado's comments regarding both the balsam garden and the relics miracle it becomes clear that he too used the abbreviated version of Burchard's account of Egypt rather than that provided by the London/Zwickau text. ${ }^{75}$ It is also noteworthy that while Tostado also made use of Sanudo's Liber secretorum fidelium crucis, he must have known Burchard's work independently, as he cites from it phrases which do not appear in the Venetian's book. ${ }^{76}$

The abbreviated version of Burchard's account of Egypt remained present in Western discourse for centuries also through the printing of textual witnesses of the Descriptio which, like the above-mentioned Oxford, Paris, Philadelphia and Vatican manuscripts, included that section (although not always in its entirety). ${ }^{77}$ Indeed, most of the editions of the Descriptio published hitherto include a unit

Babylon too there is a miracle worthy of record. In a monastery built there in honour of the blessed John the Baptist there is a chest with his relics [...] After the celebration of mass they put the chest in the river, wishing to discover where the saint wishes his relics to remain, that is in this place or in the former.'

73 Alphonsi Tostati commentaria in primam partem Matthaei, Venice: Apud Io. Baptistam et Io. Bernardum Sessam, 1596, fol. 133r-133v.

74 '...sicut scribit frater Brocardus Theutonicus...'; 'Et testatur in libro suo frater Brocardus se vidisse, cum non crederet omnibus asserentibus...' Alphonsi Tostati commentaria, fol. 133r.

75 Thus he includes the phrase 'Sed deceptos se videntes...' (Alphonsi Tostati commentaria, fol. 133r) which is a part of the abbreviated section (Appendix 2, 1. 4) but does not appear in the London/Zwickau text (cf. Appendix 1, 1l. 125-130). Similarly, describing the relics miracle, he says, as does the abbreviated version, that this ceremony takes place in order to discover whether or not the relics of Saint John wish to remain in the site to which they were taken or to return to the place from which they were removed. Alphonsi Tostati commentaria, fol. 133v.

76 For example, in his description of the balsam garden Sanudo says nothing of the additional well dug in it (p. 260). Tostado does include this detail in a manner practically identical to that of the abbreviated section. Cf. Bongars, Gesta, vol. II, p. 260; Alphonsi Tostati commentaria, fol. 133r.

77 See above, n. 55. 
devoted to Egypt. ${ }^{78}$ In all of these cases, the text provided is based on the abbreviated version rather than on the London/Zwickau redaction. Furthermore, one can identify two major families among these editions as far as the account of Egypt is concerned. The first branch includes all four subsections which appear in Appendix 2, and ends with the words 'Id retulerunt mihi Christiani et Sarraceni bona fide' (cf. Appendix 2, ll. 32-33). ${ }^{79}$ This is followed by an extraordinary autobiographical paragraph which, in all likelihood inauthentic, implies that in the sixteenth century a person such as Burchard would have been perceived as an early explorer. ${ }^{80}$ The text provided by the second family ends with the digging of the new well in the balsam garden, thus omitting paragraphs 2-4 provided by Appendix $2 .{ }^{81}$ Perhaps this version resulted from the work of an author who was skeptical with regard to miracles.

\section{Conclusion}

Having examined the early-modern printed editions of Burchard's account of Egypt, we can now return to Laurent's edition with which we have begun this article. As was noted, Laurent was aware of the existence of a section dealing with Egypt in the 1519 edition of the Descriptio but rejected its authenticity on the basis of Burchard's statement that he would only describe the Holy Land. The

78 The following comments are based on the editions listed in Röhricht, Bibliotheca, pp. 58-59. Unfortunately, Kappelli's list (Kaeppeli, Scriptores, vol. I, pp. 257-260) does not include a list of printed editions.

79 The editions included in this group are: Veridica Terre Sancte regionumque finitimarum ac in eis mirabilium descriptio, Venice: in edibus Joannis Tacuini de Tridino, 1519; Descriptio Terrae Sanctae et regionum finitimarum auctore Borchardo... Magdeburg: Paulus Donatus, 1587; Itinerarium sacrae scripturae, Magdeburg: Paulus Donatus, 1593.

80 'Peractis per decennium hiis longis et certe laboriosis peregrinationibus, nam non nisi navi vel pedibus tot regiones peragravi, querens et sepe mendicans extrema victui necessaria, incepi corpore gravescere tum propinquante senectute tum arduis laboribus perpessis. Quas ob causas statui gradum sistere, nec ultra proficisci. Erat enim mens etiam ultimos adire Indos. Revertendum igitur mihi persuasi in propriam patriam, ubi in residuo vite mee ac senectute quiescens que oculis vidi fidelibus enunciarem ac posteris describens eternam rei memoriam relinquere possem. Quod conceperam Deo clementissimo favente assecutus sum. Tibi honor, tibi gratiarum actio beatissima trinitas. Amen.' (Veridica ... descriptio [no page numbers]). The 1587 and 1593 editions provide very similar readings of this paragraph.

81 This branch includes the following editions: Novus orbis regionum ac insularum veteribus incognitarum, Basel: apud Io. Hervagium, 1532, repr. Basel, 1537; Descriptio Terrae Sanctae exactissima autore Brocardo Monacho, Antwerp: in aedibus Ioannis Steelsii, 1536; De dimensione terrae autore Casparo Peucero, Wittenberg: publisher not mentioned, 1554; De dimensione terrae autore Casparo Peucero, Wittemberg: ex typographia Simonis Gronenbergii, 1587; Palaestina seu descriptio Terrae Sanctae solertissima, Cologne: ex Officina Ioannis Crithii, 1624; Onomasticon urbium et locorum sacrae scripturae ... accessit huic editioni Brocardi monachi descriptio Terrae Sanctae, Amsterdam: Franciscus Halma, 1707. 
evidence presented above from the London and Zwickau manuscripts reveals that Burchard certainly did include in his work an account of Egypt as well as of several other regions through which he traveled, and that Laurent's argument in this regard should be rejected. What Laurent saw as evidence that the account of Egypt is inauthentic actually bears testimony to a unique moment in Burchard's work as an author, a moment in which he decided to continue documenting his travels even as he left the Holy Land. As we have seen, this specific shift should be seen within the context of a significant trend in late medieval Western travel literature, a trend to which Burchard may have become exposed in Acre. Furthermore, departing from the Holy Land, Burchard changed not only his subject matter but, to a considerable degree, also his manner of working: while his account of the Holy Land was written according to a carefully preconceived plan, his description of Egypt is a work whose structure results from the author's movement through space and the order in which various pieces of information reached his ears. Perhaps, however, this switch was too radical for Burchard's audience: as we have seen, the complete account of Egypt lay forgotten for centuries, during which an abbreviated version, which stressed holy sites and miraculous events, remained dominant, until it was rejected as inauthentic by Laurent. Within this context, the present article attempted to rescue from oblivion Burchard's complete account of Egypt and to shed light on its development and reception. 
Appendix 1

The tentative edition of Burchard's 'Egyptian section' presented here is based on the only two manuscripts which are currently known to include a complete version of this part of his work: London, British Library, Add. 18929 and Zwickau, Ratsschulbibl. 1.12.5. This is the first time that this text is published in its entirety. Parts of it have, however, been printed before: the first part of the text, as provided by the above-mentioned abbreviated version, was published by Omont, but, as we have seen, this redaction is considerably different from the parallel text of the London/Zwickau version and is the result of a significant reediting effort. Furthermore, Omont's publication, based on a sole manuscript (Paris, Bibliothèque nationale de France, Nouv. acq. lat. 781) also includes numerous flawed readings. For example, Omont repeatedly uses the form Taphyus instead of Taphnis for Tinnis, and provides 'regem huius Ethyopie in Babilonia vidi' instead of 'Regem Ethiopie huius in Babilonia captivum vidi'. Omont's text is also hard to use as it does not include identifications of the various sites mentioned. The second part of the text presented here (following 1 . 132) was published, using only the London manuscript, in an article devoted to a preliminary presentation of this manuscript. ${ }^{2}$ The text provided here is that of MS London while the apparatus presents the variants of the Zwickau manuscript $[\mathrm{Zw}]$. As a rule, orthographic variations are ignored. Numbers appear as they are in the manuscript (at times Arabic and at others Roman). [ ] = my addition; < > = redundant letters/words in MS.

[London, fol. 42r; Zwickau, fol. 140v] In kalendis Septembris ascensa galea ut navigarem in Egiptum de Ptholomaide veni ad montem Carmeli in Caypham, inde Dothan $^{\text {ii }}$ que nunc Castrum Peregrinorum dicitur, inde Cesaream Palestine. [Inde navigavi] per Antypatridem et Ioppem et Iamniam, ${ }^{3}$ per Azotum ${ }^{4}$ et Ascolonem, per Gazam et Dorre, ${ }^{5}$ que est principium solitudinis, et inde ad gulfum Larisse, ${ }^{6}$ ubi est primus portus Iudee. De gulfo isto in Rasencasse, ${ }^{7 i i i}$ que est prima civitas

Omont, 'Manuscrits', pp. 499-500; MS Vatican, fol. 15r.

Rubin, 'Burchard', pp. 184-185.

Yavne, Yibna, Ibelin.

Ashdod.

Al-Darum?

Al-'Arish.

Ras Kasrum, olim Casius mons. See Patrick Gautier Dalché, Carte, Carte marine et portulan au XIIe siècle. Le Liber de existencia riverierarum et forma Maris Nostri Mediterranei (Pise, circa 1200), Rome: École française de Rome, 1995, pp. 124, 125. 
Egipti in solitudine Pharan, et inde Pharamiam ${ }^{8}$ civitatem pulcram et munitam, sed non habitat in ea homo quia serpentes eiectis habitatoribus eam penitus possederunt. Anno domini $1284^{\text {iv }}$ in die nativitatis beate virginis, ${ }^{9 v}$ intrans Egiptum veni in Pharamiam ubi sunt [fol. 42v] hostia Nili fluminis. $\mathrm{Hec}^{\mathrm{vi}}$ civitas murata [est] quidem et bene edificata sed non est in ea aliquis habitator quia serpentes eam penitus possederunt. ${ }^{\text {vi }}$ De Pharamia ${ }^{\text {viii }}$ in Taphnim ${ }^{10}$ sunt 20 leuce; hec est Taphnis de qua dicitur in Psalmis 'fecit mirabilia in terra Egipti in cam[po] Than[eos]', ${ }^{11}$ et in qua filii Israel fuerunt commorati, etiam ${ }^{\mathrm{ix}}$ est terra ${ }^{\mathrm{x}}$ Yessen. ${ }^{12} \mathrm{De}$ 15 Taphnis usque Memfis, que nunc Damiata dicitur, sunt 15 leuce; que distat $\mathrm{a}^{\mathrm{xi}}$ mari per leu[cas] 2, ${ }^{\text {xi }}$ Pharamia vero inmediate supra mare [est]. Taphnis fuit antiquitus $^{\text {xiii }}$ valde munita, et firmo loco sita, sed hodie penitus est destructa, et pauci Bodiwini propter ubertatem terre et pascua ibi habitant in ruinis eius, et habundant ${ }^{\mathrm{xiv}}$ piscibus et avibus supra modum..$^{13}$ Damiata insuper antiqua penitus est destructa, sed fecerunt Sarraceni iuxta eam aliud casale, longum quidem sed inmunitum ad naves collocandas et merces, et habundat frumento, fructibus, ${ }^{\mathrm{xv}}$ piscibus et aliis que ad cibum pertinent, sicut Taphnis. ${ }^{14}$ Et separatur in occidentali eius <in $>^{\times v i}$ parte inter eam et veterem Damiatam rivus unus de vero alveo Nili, et etvii procedit contra aquilonem in Taphnis, et inde per fretum quoddam, quod Bayera ${ }^{15}$ dicitur, usque Pharamiam, et ingreditur ibi mare. ${ }^{16}$

Et iste ${ }^{\text {xviii }}$ est primus portus Egipti versus Terram Sanctam. Ipse vero maior rivus Nili ad 2 leucas de Damiata intrat mare, et iste ${ }^{\mathrm{xix}}$ est secundu[s]. Tertius est portus $^{\mathrm{xx}}$ in Allexandria, ubi ingreditur mare ${ }^{\mathrm{xxi}}$ maior pars Nili, qui locus distat $\mathrm{a}^{\mathrm{xxii}}$ Pharamia, ubi primus rivus ingreditur per 200 miliaria et 30 et hec ${ }^{x x i i}$ [est] 30 longitudo Egipti iuxta mare. De Alexandria usque in Babiloniam sunt similiter cc miliaria et $30^{\text {xxiv }}$ per fluvium Nilum ascendendo. De Pharamia vero per Thaphnim et Damiatam usque Babiloniam sunt ${ }^{\mathrm{xxv}} \mathrm{cc}$ miliaria tantum, per fluvium ascendendo. De Babilonia vero usque Syemem, ${ }^{17 x x v i}$ que est civitas ultima Egipti

8 Farama, Pelusium. The demise of the city was a result of Crusader attacks in 1118 and 1150. Copper, The Medieval Nile, p. 212.

September 8.

10 Tinnis.

11 Ps. 77.12.

12 Land of Goshen, Cf. Judith 1:9 in the Vulgate. Pringle, Pilgrimage, p. 320.

13 The Sultan al-Malik al-Kamil ordered the destruction of the city in 1227, probably because of fear that the Franks might be able to get hold of it. Cooper, The Medieval Nile, p. 218. The continuation of William of Tyre mentions a 'chastel de Thannis' (Recueil des historiens des croisades, historiens occidentaux, vol. II, Paris: Imprimerie Nationale, 1859, p. 597.

14 For further evidence for the desctruction of Damietta and the foundation of a 'new Damietta', see Cooper, The Medieval Nile, p. 224. Note that the location of the older Damietta is unknown.

15 Unidentified.

16 A channel seems to have existed between Damietta and Lake Tinnis. Cooper, The Medieval Nile, pp. 221, 225-226. In any case, it could not have gone North.

17 Aswan. 
contra austrum et Ethiopiam, sunt miliaria ccxl. Ista Ethiopia proprie dicitur Nubia et est tota Christiana, in qua beatus Matheus apostolus ${ }^{\text {xxvii }}$ predicavit. Regem Ethiopie huius ${ }^{\mathrm{xxvii}}$ in Babilonia $<\mathrm{m}>^{\mathrm{xxix}}$ captivum vidi.

De Damiata per Nilum ascendendo veni in Abdela ${ }^{18}$ [fol. 43r] et inde Mansoram, in quo ${ }^{\mathrm{xxx}}$ dividitur Nylus et vadit minor rivus, sicut superior, ad fretum quod est iuxta Pharamiam, et iungitur illi quod ibidem intrat mare, sicut dictum est supra. ${ }^{19}$ Inde iuxta villam quandam bonam valde, que dicitur Semenuch, ${ }^{20}$ separatur iterum alius rivus, et iste ${ }^{\mathrm{xxxi}}$ est tercius, et vadit contra aquilonem, intrans mare iuxta [erased word?] ${ }^{x x x i i}$ villam que dicitur Phathures, sed non est navigabilis rivus iste. ${ }^{\text {xxxii }}$ Item inde ascendendo, antequam perveniatur in Phiton ${ }^{\text {xxxiv }}$ [et] Ramasses, separatur quartus rivus et vadit similiter

45 ad aquilonem, intrans mare iuxta villam que Sturion appellatur. Inde, hoc est de rivo ipso usque in Phiton et Ramesses, sunt 5 leuce, et sunt iste ${ }^{\mathrm{xxxv}}$ due ${ }^{\mathrm{xxxvi}}$ super rivum hinc inde site bone. ${ }^{x x x v i i}$ Inde ad 30 miliaria est locus qui vocatur Delta grece, quia ibi Nilus dividitur et in diversa fluens totam ${ }^{\text {xxxviii }}$ Egiptum facit insulam in modum delte litere triangulam; et procedit maior rivus contra Alexandriam, 50 alter in Damiatam, ut dictum est supra. Ecce habes v rivos. De Delta usque in Elyopolim $^{21}$ sunt 3 miliaria, et ibi recedit sextus rivus, qui procedit contra aquilonem usque ad civitatem Pelbis, ${ }^{22}$ que quondam Pelusium dicebatur. ${ }^{23} \mathrm{Et}$ inde vadit per desertum versus Terram Sanctam et intrat mare iuxta civitatem Larys, a qua mare illud gulfus Leyrisse nuncupatur. Inde est ${ }^{\mathrm{xxxix}}$ una dieta usque 55 Gazam et Bersabee. Iste rivus vocatur in Scriptura proprie rivus Egipti, et in ipso erat terminus sortis Iude, sicut dicitur in libro Numerorum; ${ }^{24}$ dicitur autem a quibusdam Rinoconula, ${ }^{\mathrm{x} 25}$ a quibusdam vero Syor fluvius Egipti; non potest autem navigari. Elyopolis est villa multum bona et dives, sed non est munita, sicut nec aliqua villa in terra Egipti, preter Alexandriam et Babyloniam, sed 60 habundat fructibus et omnibus deliciis mundi; cassia fistula in magna quantitate crescit ibidem. Inde per 7 leucas est civitas Babylonia magna valde et bene munita, sita supra Nylum fluvium in littore eius orientali; transit tantum ${ }^{\text {xli }}$ rivus unus de eodem fluvio per medium eius et per civitatem Kayrum ${ }^{\text {xlii }}$ competenter magnus et revertitur ad rivum principalem in Kayro. De Babylonia ad 5 leucas ${ }^{\text {xiii }}$ sunt quedam pyramides triangule multum alte [fol. 43v], que dicuntur horrea

18 Miniet Abu-Abdallah. See Jean Richard, The Crusades c. 1071-c. 1291, trans. Jean Birrell, Cambridge: Cambridge University Press, p. 349.

This seems to refer to the Tinnis branch of the Nile. Cooper, The Medieval Nile, figure A2.14.

Samannud. Cooper, The Medieval Nile, p. 295.

Heliopolis.

Bilbeis.

23 The channel referred to here is probably the canal of Dhanb al-Timsah (Cooper, The Medieval Nile, figure A2.14). The identification of Bilbeis and Pelusium is clearly wrong.

$24 \quad$ Num. 34.5.

25 Al-'Arish. 
Ioseph fuisse, et iuxta illas sunt ruine civitatis Thebe ad 2 leucas. De ista ${ }^{x l i v}$ fuit legio Thebeorum, cui adiacet desertum Thebaydos, ${ }^{26}$ in quo fuit antiquitus multitudo magna monachorum. Supra Babyloniam Nilus habet i rivum tantum usque Syenem ${ }^{\text {xlv }}$ per miliaria cclx. . $^{\text {xvi }}$ Syene sub ipso tropico estivo sita est, unde et ibi absumitur umbra $<m>{ }^{x}$ xvii primo gradu cancri et tunc Meroe ${ }^{x l v i i i}$ proicit umbram in meridie contra austrum. ${ }^{27}$ Ortus vero Nili sciri non potest ultra, nisi usque ad montes qui sunt a sinistro Nubie, per quos descendit, et est ultra locus immeabilis, ut mihi dixerunt Nubiani.

\section{De situ Egipti ${ }^{\mathrm{xlix}}$}

Terra Egipti fere inaccessibilis est. Ab aquilone enim habet mare magnum, ubi non est accessus, nisi per naves; contra Affricum est desertum Lybie Pylenorum, ${ }^{28}$ quod habet in latitudine et longitudine dietas plures scilicet $\mathrm{xl}$. Ab austro est 80 desertum Ethiopie per 25 dietas et plus usque Nubiam; ab oriente desertum Thebaydos ${ }^{\text {li }}$ usque ad mare rubrum per 3 dietas ad locum qui Beronice ${ }^{29}$ dicitur, et est portus Egipti in littore rubri maris ${ }^{\text {lii }}$ volentiliii versus Indiam navigare. Contra vulturnum vero et septentrionem est desertum magnum usque ad Terram sanctam, in quo filii Israel recedentes de Egipto morati sunt xl annis.

85 Et dixerunt mihi Sarraceni, etiam ${ }^{\text {liv }}$ Christiani qui sunt in Egipto idem fatebantur presentibus Sarracenis, quod amplius quam ccc milia Christianorum sunt in Egipto, et ecclesie et claustra multa. In Babylonia vero et in Kayro sunt ecclesie xl et amplius, et in aliis civitatibus et villis Egipti sunt ecclesie plures, quas etiam ${ }^{\text {lv }}$ causa orationis intravi cum essem ibi.

90 Sunt etiam in Egipto casalia multa et populus multus valde, qui non potest estimari. Sunt ibi Bodiwini, qui multitudine ceteros habitatores terre vincunt; Sarraceni tamen dominantur in terra, sed timent plurimum Bodiwinos. Turci vero, sive Turkomanni, sunt superiores Sarracenis pro eo quod soldani per tempora longa $^{\text {lvi }}$ fuerunt de gente illa, et melior militia que est in Egipto est de gente illa. Ivii

[fol. 44r] Egiptus fere est triangula, duobus lateribus equalibus, tertio breviore; et sunt in tribus cornibus huius trianguli site civitates s. iste, ${ }^{\text {Iviii }}$ Laris, Babilonia, Alexandria. Volvit aut[em] Egiptus in gyro de Laris per Babyloniam in Alexandria[m] $]^{\text {lix }}$ et inde iterum in Laris 950 miliaria; de Babilonia vero usque 100 Syenem et inde usque in Meroen, licet sit longitudo magna, latitudo fere ${ }^{\mathrm{lx}}$ nulla est, quia via illa procedit per ascensum Nili, qui habet montes altos hinc inde, et

\footnotetext{
Cf. Willelmus, Chronicon, vol. II, p. 897 and see the discussion above.

See the discussion above.

Burchard probably had in mind Arae Philaenorum.

2 Berenice.
} 
terram omnino desertam, nisi super ipsum fluvium; sed et ${ }^{\text {lxi }}$ illa loca sunt barbare habitationis.

In Elyopoli et in ${ }^{\text {lxii }}$ Babylonia ostenduntur loca in quibus Virgo ${ }^{\text {lxii }}$ mansit cum puero Ihesu, quando a facie Herodis fugit in Egiptum, et casus ydolorum et templorum, secundum prophetiam Ysa[ie]..$^{30}$ Sana est terra ${ }^{\text {lxiv }}$ Egipti, et aer sanus et cibi convenientes; et est terra multa ${ }^{\mathrm{lxv}}$ temperata, immo temperatior ${ }^{\mathrm{lxvi}}$ Syria et Palestina, cum tamen secundum situm locorum deberet merito contrarium inveniri. Inter Babyloniam et Elyopolim medio loco fere est ortus balsami de quo 110 dictum est prius, ${ }^{\text {lxviis1 }}$ et habet terram fere albam. Erat autem eo tempore cum essem ibi, scilicet in festo Michahelis, ${ }^{32}$ lignum balsami satis humile, scilicet palme et dimidie in altitudine, habens folia modica sicut ruta, sed parum albiora, et tuli de ipsa ${ }^{\text {lxviii }}$ in bona quantitate mecum. Modum eciam colligendi balsamum cultores ostenderunt mihi; decerpebant enim folium de ipso stipite, quia folia 115 stipiti adherent sicut in ysopo ${ }^{33}$ et unum tantum stipitem habet, licet plures in uno stent cespite, interdum 6 vel 7 vel plures. Decerpto autem folio contra radium solis, statim de ruptura ipsa egreditur gutta lucidissima odorifferra valde; et iste $e^{\text {lxix }}$ est liquor balsami, qui colligitur in phialis vitreis, et preparatur modo debito et balsamus efficitur. Et si folium illud decerperetur alibi quam contra 120 radium solis, nichil ${ }^{1 \mathrm{xx}}$ distillaret. Rigatur autem ortus iste ${ }^{\mathrm{lxxi}}$ de quodam fonte parvo sed ubertim ${ }^{\text {lxxii }}$ effluente, in quo [fol. 44v] beata virgo puerum Ihesum dicitur pluries baptizasse ${ }^{\text {lxxiii }}$ et pannos eius lavisse, cum esset in Egipto, et est ibidem lapis in quo dicitur eos siccasse. Et hec omnia in veneratione ${ }^{\text {lxiv }}$ habentur a Christianis et Sarracenis.

125 Et quia fons iste ${ }^{\mathrm{lxxv}}$ modicus est ita quod non sufficeret ${ }^{\mathrm{lxxvi}}$ irrigare totum ortum, Sarraceni fecerunt alium profundum fontem ${ }^{\mathrm{lxxvii}}$ iuxta illum, de quo boves per rotam trahunt aquam, quam Sarraceni per canalem currere faciunt ad fontem Christi sperantes quod ex commixtione cum aqual ${ }^{\text {xxviii }}$ fontis Christi accipiat virtutem fecundandi ortum balsami. Nec spe sua fraudantur. Nunc enim per 130 aquas istas ${ }^{\text {lxix }}$ fecundatur ortus balsami quod alias non fieret ullo modo. De hiis bubus quomodo feriam servant in Dominica dixi ${ }^{\mathrm{lxx} x}$ supra.

De Babylonia recedens ductus sum ad locum ubi erant 6 leones et 6 elephantes et 60 strutiones in curia et onager[i] plures. Vidi etiam ibi quoddam mirabile

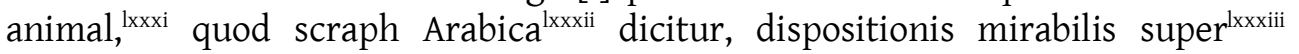
135 modum. Habet enim in longitudine pedes 16 vel amplius, pellem sicut iuvenis capreolus $^{\mathrm{lxxxiv}}$ maculosam, ${ }^{\mathrm{lxxxv}} s$ [cilicet] rubeum colorem albo permixtum. Priores

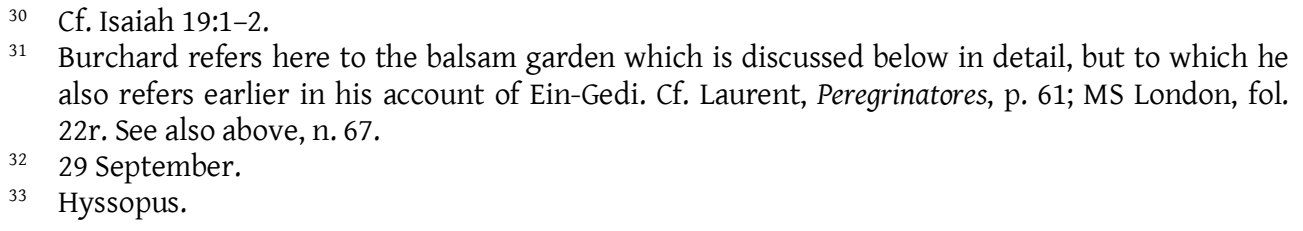


pedes et crura ita sunt alta, et collum ita longum, quod pro certo dico quod tectum ecclesie vestre in Magedeburc tangere posset ore. Posteriora vero crura demissa sunt, et corpus similiter, ita ut modico ibi sic altius quam camelus. Est 140 autem animal ${ }^{\mathrm{lxxxvi}}$ in multis terris rarum et invisum. ${ }^{34}$

Item vidi ecclesiam Sancti Iohannis Baptiste ibidem, in qua sunt reliquie eius. Istas tollunt Sarraceni cum soldano singulis annis in festo eius, ${ }^{1 \times x x v i i}$ et portant eas ad $\mathrm{v}$ leucas infra civitatem Babiloniam, et astante soldano ponunt eas in fluvium Nilum, qui est inpetuosus supra modum, et mox, ipso soldano cum toto populo 145 vidente, scrinium in quo sunt ipse reliquie ${ }^{\mathrm{lxx} x v i i}$ cum tanta ${ }^{\mathrm{lxx} x \mathrm{x}}$ celeritate contra impetum aque [fol. 45r] currit usque in Babyloniam in pristinam ecclesiam redeundo, quod nec soldanus cum suis potest tam cito in equis illuc currere ullo modo. In hoc ${ }^{\mathrm{xc}}$ facto Sarraceni prenosticantur ${ }^{\mathrm{xci}}$ fluvium amplius ${ }^{\mathrm{xci}}$ crescere et terram uberius ${ }^{x \text { ciii irrigare. }}{ }^{35}$

Multi Christiani sunt in Egipto, et dixerunt mihi 8 sacerdotes Christiani in Ramesses presentibus Sarracenis, et Sarraceni hoc verum esse fatebantur, quod essent ibi pro certo $6000^{\text {xiv }}$ milia Christianorum, qui sunt devoti satis et multe abstinentie, et ${ }^{\mathrm{xcv}}$ pro nomine ${ }^{\mathrm{xcvi}}$ Ihesu multi ${ }^{\mathrm{xcvii}}$ in Egipto hodie martirio coronantur. Quidam enim nolentes negare nomen Christi usque ad mortem 155 flagellantur. Quidam et exviii $^{\text {crucifiguntur, quidam comburuntur, quidam }}{ }^{\text {xcix }}$ decollantur, perfodiuntur et ceteris suppliciis affecti regna celestia assecuntur.

Videtur autem mihi, ${ }^{c}$ et idem est iudicium plurium, quod Babylonia ${ }^{\text {ci }}$ duplo excedit $^{\text {cii }}$ magnitudinem Parisiensis civitatis adiuncta Kayro preter campum qui coniungit eas. In populositate non est comparatio, nec credo sub celo in una 160 civitate tantum esse populum sicut in Babylonia. [I]mmo dicunt mercatores pro certo quod tota Tuscia non habet tantum populum, et miror quod tota Egiptus potest tantum populum sustentare.

Certissimum tamen est quod nec ipsa posset subsistere si non esset subsidium aliarum regionum. Nichil autem ${ }^{\text {ciii }}$ habundat in Egipto nisi panis et aqua et fructus

34 For evidence on Cairo's medieval menagerie, see Thierry Buquet, 'Animalia extranea et stupenda ad videndum. Describing and Naming Exotic Beasts in Cairo Sultan's Menagerie', in Francisco de Asís García García, Mónica Ann Walker Vadillo and María Victoria Chico Picaza (eds), Animals and Otherness in the Middle Ages: Perspectives Across Disciplines, Oxford: Archaeopress, 2013, pp. 2534 .

35 I have found no reference to any similar account. The closest description seems to be that of the Coptic festival of the martyr, though it differs in significant points from that provided by Burchard. For example, in the festival of the martyr it was the finger of a Coptic martyr that was being placed in the Nile rather than relics of Saint John. However, this Coptic festival does resemble that which is depicted by Burchard in the connection created between the placing of a relic in the Nile and the river's inundation. The presence of prominent Mamluks, though not of the Sultan himself, is also attested to in a Muslim source describing this festival. Huda Lufti, 'Coptic Festivals of the Nile: Aberrations of the Past?', in Thomas Philipp and Ulrich Haarmann (eds), The Mamluks in Egyptian Politics and Society, Cambridge: Cambridge University Press, 1998, pp. 263-268. 
165 et sal; Fructus dico poma, arangia, lemones, ${ }^{\mathrm{civ}}$ poma paradisi, cucurbite, ${ }^{\mathrm{cv}}$ cucumeres, cytrulli, pepones, cepe et allium. Ceterum, pira, poma, nuces, cerasa, ${ }^{\text {cvi }}$ brunella penitus non sunt ibi. Ligna pro edificiis vel pro navibus fabricandis non sunt ibi, nec posset tota Egiptus de suis lignis construere navem unam, nisi ligna ab extraneis portarentur, vel etiam ipse naves, et ideo lata est ${ }^{\text {cvii }}$ 170 sententia contra tales.

Lapides penitus non sunt ibi, nisi in Babylonia [fol. 45v] et in Kayro, nec habet tota Egiptus domum lapideam nisi ille due civitates. Tamen edificia sunt ibi quantum $^{\text {cviii }}$ ad apparentiam pulcra nimis, sed materia eorum vilis est. ${ }^{\text {cix }}$ Sunt enim parietes edificiorum in civitatibus facti de harundine et calce optime liniti 175 intrinsecus et extrinsecus supra lutum et desuper picti $^{\mathrm{cx}}$ auro et lazurio et opere musivoci ita pulcre quod stupor est videre, et domus que foris apparet vilissima, postquam intraveris eam ${ }^{\text {cxii }}$ crederes paradysum.

Monete ${ }^{\text {cxii }}$ auri, ${ }^{\text {cxiv }}$ argenti, stagni, ${ }^{\text {cxv }}$ plumbi, ferri, cupri, non sunt ibi. ${ }^{36 \mathrm{cxvi}}$ Oleum, mel, vinum, ${ }^{\text {cxvii }}$ panni lanei non sunt ibi. ${ }^{\text {cxviii }}$ Certissimum est quod nisi 180 mercatores de Veneciis, Pysis, Genua, Massilia, Messana, Brundusio, et civitatibus aliis maritimis ista apportarent, ${ }^{\text {cxix }}$ Egiptus non posset habitari, ${ }^{\text {cxx }}$ et si istic ${ }^{\text {cxxi }}$ cohiberentur non posset subsistere uno anno. Hoc ${ }^{\text {cxxii }}$ mercatores ipsi ${ }^{\text {cxxii }}$ fatentur. Ville non possunt habere domos harundineas, sed de luto in modum clibani faciunt sibi domos, nec est in tota Egipto aliqua municio civitatis vel castri quod c 185 militibus posset resistere dimidio die, nisi Alexandria, Babylonia et Kayrum, et una ex istis capta, Egiptus perdita esset tota.

Horrea Ioseph ibi vidi excelsa supra modum ita ut ad dietam et ad $1 / 2$ miliare videantur. ${ }^{\text {cxxiv }}$ Incole vocant ea Horrea Ioseph, sed mihi videntur esse sepulcra sive tytuli sepulcrorum. Sunt enim pyramides triangule tres in uno loco habentes 190 ab angulo usque ad angulum 180 cubitos virilis stature et tante altitudinis quod nullo modo potest arcus usque ad summum iacere licet sit sepius attemptatum. Ego credo esse pyramides ${ }^{\text {cxxv }}$ Alexandri Magni qui in veritate ibi fuit ${ }^{\text {cxxvi }}$ mortuus et sepultus et quorumdam regum aliorum. Horrea tamen Ioseph credo iuxta [fol. 46r] eundem locum fuisse quia adhuc apparent ibi signa ${ }^{\text {cxxvii }}$ quedam edificii 195 amplissimi ${ }^{\text {cxxviii }}$ que sunt fere ${ }^{\text {cxxix }}$ arena obruta, vento eam illuc ${ }^{\text {cxxx }}$ iaciente $^{\text {cxxxi }}$ de deserto Thebaydos, quod ibidem incipit ad unum miliare. In quo sancti patres antiquitus morabantur. Facte sunt pyramides de maximis lapidibus sxxii ita quod non vidi maiores in edificio unquam poni. Distat autem a Babylonia $a^{\text {cxxxiii }}$ fere per 3 miliaria teutonica. ${ }^{\text {cxxiv }}$ Multa miranda ${ }^{\text {cxxxv }}$ alia vidi in Egipto que scribere longum esset. ${ }^{\text {cxxxvi }}$

36 This comment is difficult to understand, as there was regular minting activity in Egypt during the Mamluk period save in specific periods. Warren C. Schultz, 'The Monetary History of Egypt, 642-1517', in Martin W. Daly (ed.), The Cambridge History of Egypt, 2 vols, Cambridge: Cambridge University Press, 1998, vol. I, pp. 333-334. Perhaps in this case, MS Zwickau's reading, according to which no mines can be found in Egypt, should be preferred. 


\begin{tabular}{|c|c|c|c|}
\hline i. & galeha Zw & & civitatem \\
\hline ii. & Doram Zw & & miliaria ccxl'. \\
\hline iii. & Rasecasse Zw & xlvii. & umbra Zw \\
\hline iv. & mlxxxiiii Zw & xlviii. & Merore Zw \\
\hline v. & Marie virginis Zw & xlix. & Zw omits titulus \\
\hline vi. & predicta add. Zw & 1. & in add. Zw \\
\hline vii. & inde scilicet add. Zw & li. & Theabydos London, Thebaidos \\
\hline viii. & usque add. Zw & & $\mathrm{Zw}$ \\
\hline ix. & etiam om. Zw & lii. & maris rubri Zw \\
\hline $\mathrm{x}$. & et in terra $\mathrm{Zw}$ & liii. & voluenti Zw \\
\hline xi. & de Zw & liv. & et $\mathrm{Zw}$ \\
\hline xii. & per 2 leucas Zw & lv. & et Zw \\
\hline xiii. & civitas add. Zw & lvi. & longa tempora Zw \\
\hline $\begin{array}{l}\text { xiv. } \\
\text { xv. }\end{array}$ & $\begin{array}{l}\text { habundat Zw } \\
\text { et add. Zw }\end{array}$ & lvii. & $\begin{array}{l}\text { 'et melior...de gente illa' om. } \\
\mathrm{ZW}\end{array}$ \\
\hline xvi. & in om. Zw & lviii. & ille Zw \\
\hline xvii. & et om. Zw & lix. & Alexandriam Zw \\
\hline xviii. & ille Zw & lx. & vero Zw \\
\hline xix. & ille Zw & lxi. & et om. Zw \\
\hline $\mathrm{xx}$. & tertius vero portus est Zw & lxii. & in om. $\mathrm{Zw}$ \\
\hline xxi. & mare om. $\mathrm{Zw}$ & lxiii. & Maria add. Zw \\
\hline xxii. & de Zw & lxiv. & Sana terra est terra $[\mathrm{sic}] \mathrm{Zw}$ \\
\hline xxiii. & est Zw & lxv. & multum Zw \\
\hline xxiv. & 200 et 30 miliaria $\mathrm{Zw}$ & lxvi. & temperantior Zw \\
\hline $\mathrm{xxV}$. & sunt om. Zw & lxvii. & supra Zw \\
\hline xxvi. & Syenen Zw & lxviii. & de ipso ligno $\mathrm{Zw}$ \\
\hline xxvii. & apostolus om. Zw & lxix. & ille Zw \\
\hline xxviii. & huius Ethiopie Zw & lxx. & 'sti' add. and deleted Zw \\
\hline xxix. & Babylonia Zw & lxxi. & ille Zw \\
\hline $\mathrm{xxx}$. & loco add. Zw & lxxii. & ubere $\mathrm{Zw}$ \\
\hline xxxi. & ille Zw & lxxiii. & balniasse? Zw \\
\hline xxxii. & $\begin{array}{l}\mathrm{Zw} \text { does not have anything } \\
\text { between the words 'iuxta' and }\end{array}$ & $\begin{array}{l}\text { lxxiv. } \\
\text { lxxv. }\end{array}$ & $\begin{array}{l}\text { in om.; veneracioni } \mathrm{Zw} \\
\text { ille } \mathrm{Zw}\end{array}$ \\
\hline & $\begin{array}{l}\text { ‘villam’. } \\
\text { ille Zw }\end{array}$ & lxxvi. & $\begin{array}{l}\text { suffeceret London, sufficeret } \\
\mathrm{Zw}\end{array}$ \\
\hline $\begin{array}{l}\text { Axxin. } \\
\text { xxxiv. }\end{array}$ & $\begin{array}{l}111 \mathrm{~L} \text { ZW } \\
\text { et add. Zw }\end{array}$ & lxxvii. & $\begin{array}{l}\mathrm{ZW} \\
\text { fontem om. } \mathrm{Zw}\end{array}$ \\
\hline xxxv. & ille Zw & lxxviii. & tamquam replaces two last \\
\hline xxxvi. & ville add. Zw & & words Zw \\
\hline xxxvii. & valde add. Zw & lxxix. & illas Zw \\
\hline xxxviii. & totum Zw & lxxx. & dictum est $\mathrm{ZW}$ \\
\hline xxxix. & enim add. Zw & lxxxi. & animal mirabile Zw \\
\hline & Rynoconsa? Zw & lxxxii. & arabice $\mathrm{Zw}$ \\
\hline & tamen Zw & lxxxiii. & super om. Zw \\
\hline xlii. & et add. Zw & lxxxiv. & capreolus iuvenis $\mathrm{ZW}$ \\
\hline xliii. & laucas London, leucas Zw & lxxxv. & imiraculosam Zw \\
\hline xliv. & illa Zw & lxxxvi. & illud add. Zw \\
\hline xlv. & Senen Zw & lxxxvii. & ipsius Zw \\
\hline xlvi. & $\begin{array}{l}\text { ccxl Zw. Zw then adds: 'et inde } \\
\text { usque ad meroen [Meroë] }\end{array}$ & $\begin{array}{l}\text { lxxxviii. } \\
\text { lxxxix. }\end{array}$ & $\begin{array}{l}\text { reliquie ipse Zw } \\
\text { tota } \mathrm{Zw}\end{array}$ \\
\hline
\end{tabular}


A Missing Link in European Travel Literature

\begin{tabular}{|c|c|}
\hline $\begin{array}{l}\text { xc. } \\
\text { xci. }\end{array}$ & $\begin{array}{l}\text { festo add. and deleted } \mathrm{Zw} \\
\text { pronosticantur } \mathrm{Zw}\end{array}$ \\
\hline xci. & pronosticantur ZW \\
\hline iii. & nd deleted Zw \\
\hline ciii. & $\begin{array}{l}\text { melius instead of uberius } \mathrm{Zw} \\
\text { sexcenta } \mathrm{Zw}\end{array}$ \\
\hline cv. & multi add. Zw \\
\hline vi. & domini add. Zw \\
\hline vii. & multio \\
\hline $\begin{array}{l}\text { xcviii. } \\
\text { xcix. }\end{array}$ & $\begin{array}{l}\text { et om. } \mathrm{Zw} \\
\text { quidam om. } \mathrm{Zw}\end{array}$ \\
\hline c. & add. $\mathrm{Zw}$ \\
\hline Cl. & om. Zw \\
\hline ii. & $\mathrm{Zw}$ \\
\hline iii. & enir \\
\hline civ. & et add. Zw \\
\hline cV. & $\begin{array}{l}\text { cocrobite London, cucrobite } \\
\mathrm{Zw}\end{array}$ \\
\hline cvi. & cerusa London, $\mathrm{Zw}$ \\
\hline jii. & est 1 \\
\hline cviii. & quan \\
\hline cix. & est \\
\hline $\mathrm{X}$. & picte? Zw \\
\hline $\mathrm{xi}$. & sivo om. Zw \\
\hline rii. & w \\
\hline xiii. & $\min$ \\
\hline xiv. & $\operatorname{vel} a$ \\
\hline rv. & ndon, Zw \\
\hline rvi. & item \\
\hline vii. & ; mel om. Zw \\
\hline xviii. & et $a$ \\
\hline xix. & egiptiis add. $\mathrm{Zw}$ \\
\hline $\mathrm{xx}$. & inhabitari Zw \\
\hline xxi. & mercatores add. Zw \\
\hline cxxii. & hec Zw \\
\hline cxxiii. & ipsi mercatores Zw \\
\hline cxxiv. & $\begin{array}{l}\text { supra modum ita ut dicam } \\
\text { [last three last words seem to } \\
\text { have been deleted by the } \\
\text { scribe] Zw }\end{array}$ \\
\hline cxxv. & puramidem 7 \\
\hline xvi. & fuit \\
\hline cxxvii. & $\begin{array}{l}\mathrm{Zw} \text { has here a word which I } \\
\text { am unable to read instead of } \\
\text { signa. }\end{array}$ \\
\hline $\begin{array}{l}\text { cxxviii. } \\
\text { cxxix. }\end{array}$ & $\begin{array}{l}\text { edificia amplissima Zw } \\
\text { omnino add. Zw }\end{array}$ \\
\hline cxxx. & $\begin{array}{l}\text { Zw seems to have originally } \\
\text { had 'hic', which was then } \\
\text { changed into 'illuc.' } \\
\text { iacentem Zw }\end{array}$ \\
\hline
\end{tabular}

cxxxii. autem pyramides ille de lapidibus maximis $\mathrm{ZW}$

cxxxiii. et distant de Babilonia et de Karo Zw

cxxxiv. ut videtur add. $\mathrm{Zw}$

cxxxv. miranda om. $\mathrm{Zw}$

cxxxvi. que que [sic] longum scribere esset Zw 
Appendix 2

This appendix includes a tentative edition of the four final paragraphs of Burchard's account of Egypt as provided by the abbreviated version. This text was previously edited by Omont on the basis of one manuscript: Paris, Bibliothèque nationale de France, Nouv. acq. lat. $781 .{ }^{1}$ As we have seen, this part of the abbreviated version differs markedly from the parallel section of the complete account transmitted by the London and Zwickau manuscripts. The text presented below is that of Vatican, Urb. lat. 393, with variants from the following MSS provided by the apparatus:

Oxford, Bodleian Library, Lat. Hist. e. 1, fols 31r-31v [0].

Paris, Bibliothèque nationale de France, Nouv. acq. lat. 288, fols 44v-45r [BnF]. Philadelphia, UPenn Ms. Codex 60, fols 42r-42v [Ph].

I also refer in the apparatus to Omont's edition [Omont].

[15v] Et quia fons iste est modicus ${ }^{\mathrm{i}}$ admodum ita quod ${ }^{\mathrm{ii}}$ non sufficeret irrigare ortum totum, iii Sarraceni fecerunt alium ${ }^{\text {iv }}$ profundum iuxta illum de quo quatuor boves $^{v}$ per rotam quandam aquam trahunt sperantes quod propter vicinitatem fontis ${ }^{\text {vi }}$ illius $^{\text {vii }}$ sortiretur virtutem ampliorem, sed deceptos se videntes <se deceptos $>^{\text {viii }}$ fecerunt canalem de suo fonte ${ }^{\mathrm{ix}}$ ad fontem Christi, et per ipsum canalem $^{\mathrm{x}}$ fecerunt ${ }^{\mathrm{xi}}$ transire aquas $^{\mathrm{xii}}$ fontis sui ${ }^{\mathrm{xiii}}$ per $^{\mathrm{xiv}}$ aquas $^{\mathrm{xv}}$ fontis Christi, immo per ipsum fontem, sperantes quod ex commixtione cum aqua fontis Christi aqua fontis $^{\text {xii }}$ sui haberet virtutem ortum balsami fecundandi, nec eos fefellit opinio. Nunc enim ${ }^{\text {xvii }}$ per istas aquas fecundatur ortus ${ }^{\text {xviii }}$ quod non fieret alias ullo modo.

10 Est preterea aliud ${ }^{\mathrm{xix}}$ mirabile et $^{\mathrm{xx}}$ attestans veritati ${ }^{\mathrm{xxi}}$ fidei Christiane sicut dictum est supra quod a meridie sabbati usque ad ortum solis in die lune boves qui trahunt aquam ipsam ${ }^{\text {xii }}$ cessant a labore ${ }^{\text {xiii }}$ et nullo modo volunt amplius ${ }^{\text {xiv }}$ aquam $^{\mathrm{xxv}}$ trahere etiam si in frustra conciderentur. Istud oculis meis vidi cum

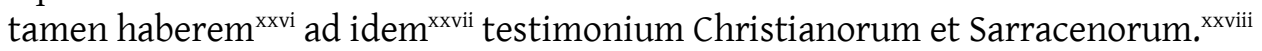

15 In fonte isto ${ }^{\mathrm{xxix}}$ ego lavi totum corpus meum. Similiter faciunt Christiani et Sarraceni. Sarraceni etiam ${ }^{\mathrm{xxx}}$ quendam fetorem teterimum habent ${ }^{\mathrm{xxx}}$ quem $^{\mathrm{xxxii}}$ nullo modo possunt ${ }^{\mathrm{xxx} x i i}$ abolere nisi baptizentur ${ }^{\mathrm{xxxiv}}$ et maxime in fonte isto. ${ }^{\mathrm{xxx}}$ Unde pueros $\operatorname{suos}^{\mathrm{xxxvi}}$ et interdum semet ipsos ${ }^{\mathrm{xxxvii}}$ baptizant non ut effectum baptismi sacramentalis consequantur sed ut fetorem istum ${ }^{\text {xxxviii }}$ valeant abolere.

20 Est ${ }^{\text {xxxix }}$ etiam aliud miraculum in Babylonia memoria dignum. Est enim ibidem quoddam monasterium $^{\mathrm{xl}}$ in honore beati Johannis baptiste ${ }^{\mathrm{xli}}$ factum et habetur ibi scrinium quoddam ${ }^{\text {xlii }}$ non magnum in quo sunt incluse reliquie eiusdem sancti. ${ }^{\text {xliii }}$

1 Omont, 'Manuscrits', pp. 502-503. 
Consuetudo autem est non solum Christianis sed etiam Sarracenis in festo eius ${ }^{\text {xliv }}$ frequentare locum istum. ${ }^{\text {lv }}$ Sarraceni enim multum honorant ${ }^{\mathrm{xlvi}}$ Johannem

25 baptistam. Unde similiter ${ }^{x \text { lvii }}$ cum christianis tollunt ${ }^{x v i i i}$ scrinium istud $^{x l i x}$ cum reliquiis istis deportantes illud per quinque ${ }^{1}[16 \mathrm{r}]$ leucas per descensum fluminis Nyli $^{\text {li }}$ ad aliam ecclesiam ${ }^{\text {lii }}$ monachorum similiter in honore eius ${ }^{\text {liii }}$ factam, et, postquam ibidem $^{\text {liv }}$ fuerit $^{\text {lv }}$ missa dicta ponunt ${ }^{\text {lvi }}$ scrinium in fluvium ${ }^{\text {lvii }}$ probare volentes utrum beatus Johannes velit ibi reliquias suas manere ${ }^{\text {lviii }}$ vel ad locum ${ }^{\text {lix }}$ reducere priorem. Sed mox in oculis omnium scrinium ${ }^{\mathrm{lx}}$ contra inpetum Nyli qui utique valde est violentus ${ }^{\mathrm{lxi}}$ tanta velocitate sursum currit ${ }^{\mathrm{lxi}}$ et redit ad locum suum quod nec hii qui in equis currunt illuc valeant citius pervenire. ${ }^{\text {lxii }}$ Istud retulerunt $^{\text {lxiv }}$ omnes Egyptii et Christiani et Sarraceni bona fide. Explicit. ${ }^{\text {lxv }}$ 


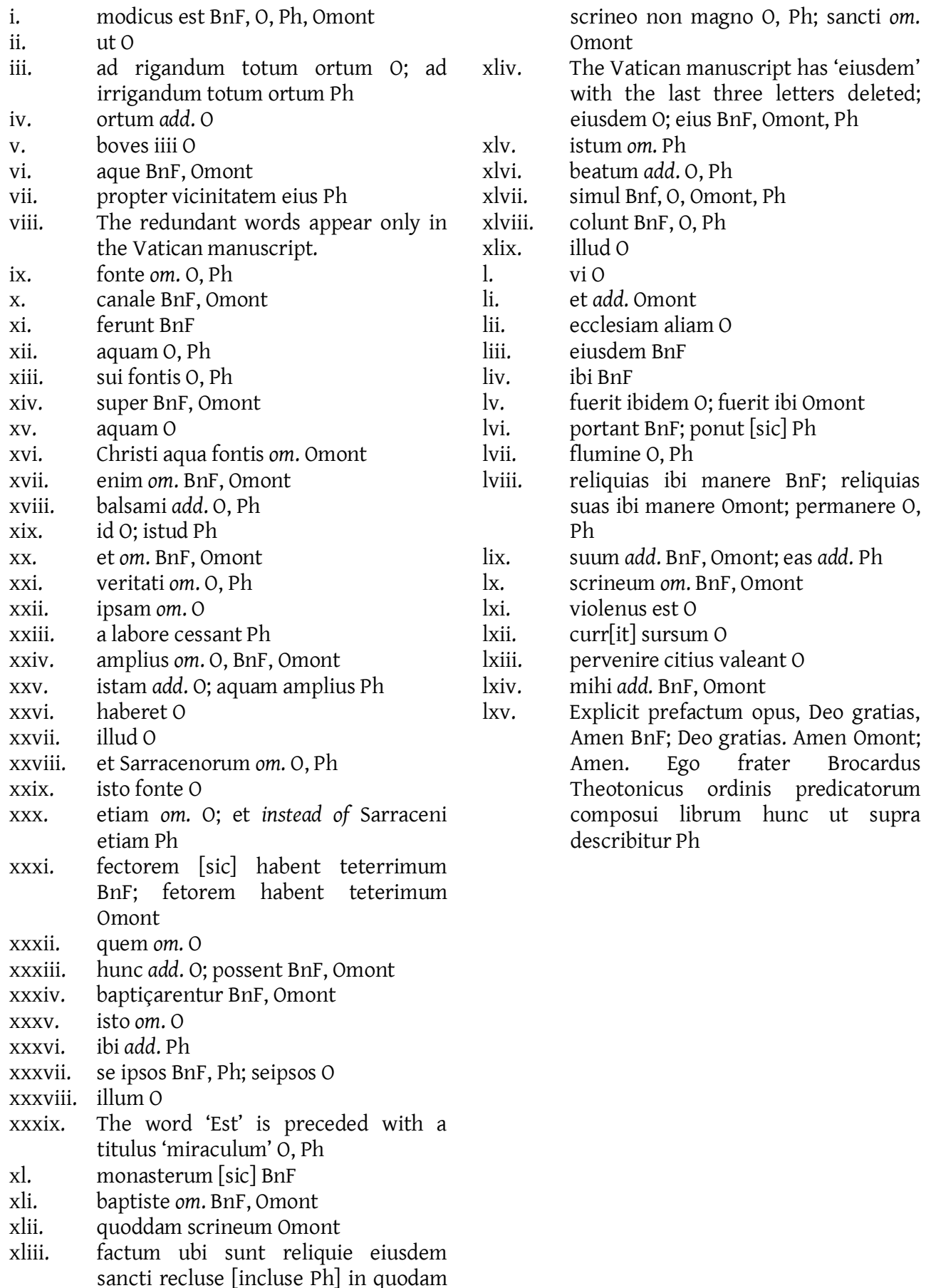

